\title{
Trade liberalization and informality in Argentina: exploring the adjustment mechanisms
}

\author{
Guillermo Cruces ${ }^{1,2,3 \dagger}$, Guido Porto ${ }^{4^{*}+}$ (1) and Mariana Viollaz ${ }^{1 \dagger}$
}

\author{
*Correspondence: \\ guido.porto@depeco.econo. \\ unlp.edu.ar \\ ${ }^{\dagger}$ Guillermo Cruces, Guido \\ Porto and Mariana Viollaz \\ contributed equally \\ ${ }^{4}$ Departamento de \\ Economía, Universidad \\ Nacional de La Plata (UNLP), \\ Argentina, Calle 6 e/ 47 y 48 , \\ Piso 3, Oficina 322, La Plata, \\ Provincia de Buenos Aires, \\ Argentina \\ Full list of author information \\ is available at the end of the \\ article
}

\begin{abstract}
This paper studies the link between trade reforms and labor informality in Argentina using a long time series spanning the 1980-2001 period. We explore cross-section mechanisms, that operate at the industry level, and time-series mechanisms, that operate at a general equilibrium level. We argue that firms can substitute formal with informal workers to smooth a negative trade shock. In this setting, industries exposed to larger tariffs cuts could experience increases in informality. In general equilibrium, there can be additional aggregate impacts in both manufacturing and non-traded sectors through workers reallocation among sectors, wage adjustments, and firm entry and exit. Using the cross-section variation of the data and an instrumental variable strategy we explore empirically the cross-section mechanisms. We find that reductions in industry tariffs increase labor informality, and the effect is differentially stronger in industries with a larger share of small-size firms. Using the time-series variation of the data, we are able to identify some of the general equilibrium effects. We find that the fall in the average national tariff decreased aggregate informality in the manufacturing sector but increased it in the non-traded sector.
\end{abstract}

Keywords: Trade liberalization, Labor informality, Cross-section mechanisms, Timeseries mechanisms, Argentina

JEL Classification: F13, F14

\section{Introduction}

Economic theory indicates that trade liberalization should lead to a reallocation of factors from protected to comparative advantage sectors, but the empirical evidence for developing countries often unveils more complex dynamic responses (Wacziarg and Wallack 2004; Menezes-Filho and Muendler 2011; Dix-Carneiro and Kovak 2015). In the literature, this is typically explained by limited factor mobility caused by reallocation costs (Atolia 2007; Artuc et al. 2010; Dix-Carneiro 2014). In this paper, we focus instead on labor informality as an additional trade adjustment mechanism. Informality is a relevant margin of adjustment for labor demand and labor supply in developing countries and this margin of adjustment can be affected by trade reforms (Currie and Harrison 1997; Goldberg and Pavcnik 2003; Levy 2008; Galiani and Weinschelbaum 2011; Dix-Carneiro and Kovak 2017). We build on this literature to explore how trade reforms

(c) The Author(s) 2018. This article is distributed under the terms of the Creative Commons Attribution 4.0 International License (http://creativecommons.org/licenses/by/4.0/), which permits unrestricted use, distribution, and reproduction in any medium, provided you give appropriate credit to the original author(s) and the source, provide a link to the Creative Commons license, and indicate if changes were made. 
affect labor informality and to identify various partial and general equilibrium mechanisms. Following Galiani and Porto (2010), we exploit a long time series of trade reforms and informality for Argentina.

In the trade literature, firms respond to tariffs cuts by reducing wages and by firing workers who reallocate to comparative advantage sectors. In turn, if informal workers are "cheaper" than formal workers, because of various taxes associated with formality, firms can increase the fraction of informal workers as an adjustment mechanism. Thus, increasing tax evasion could be a strategy to smooth the negative trade shock. In this setting, industries exposed to larger tariff cuts could experience increases in informality. In general equilibrium, there can be additional aggregate impacts in both manufacturing and non-traded sectors. These additional impacts are explained by the usual trade adjustment mechanisms of workers reallocation among sectors, wage adjustments, and firm entry and exit. For instance, as workers reallocate out of an industry, they can get absorbed into the non-traded sector. To the extent that these workers are employed informally, tariff cuts can be associated with higher informality in the non-traded sector. However, if, for tax evasion reasons, exposed industries fire formal workers in higher proportion relative to informal workers, formal wages may decline with respect to informal wages. Formal workers may become cheaper and informality may decline, both in manufactures and in non-traded sectors. Further, the loss of tariff protection can induce firms to exit the market. As more efficient firms stay, provided they are likely to be more formal than smaller exiting firms, informality can decline as well through this channel. In the literature, it has been often difficult to disentangle these different mechanisms.

In this paper, we study these mechanisms in Argentina using a long time series of tariffs and individual workers spanning the 1980-2001 period (Galiani and Porto 2010). During this period, Argentina experienced a sizeable increase in overall labor informality and important trade policy changes, leading to substantial time-series and inter-industry variation in tariffs for the manufacturing sector. Using the cross-section variation in the data, we explore the partial equilibrium mechanisms. We find that trade liberalization, measured as cross-industry reductions in tariffs, raised labor informality at the industry level. Additionally, the magnitude of this effect depends on the size of the firms in each industry. When small firms prevail, we find evidence that firms substitute informal workers for formal workers, but this effect fades away as average firm size within industries increases. This can be explained by less efficient tax evasion controls for smaller firms. Using the time-series variation of the data, we are able to identify some of the general equilibrium effects of trade reforms. We find that, conditional on the structure of sectoral protection, the fall in the average national tariff decreased aggregate informality in the manufacturing sector but increased it in the non-traded sector. This result can be rationalized with an outflow of workers from manufacturing, a resulting wage adjustment that makes formality cheaper, and the exit of small firms because of foreign competition. In the non-traded sector, the evidence suggests that the inflow of displaced manufacturing workers finds mostly informal jobs.

These results can help to explain some of the conflicting evidence previously documented in the literature. Goldberg and Pavcnik (2003), Menezes-Filho and Muendler (2011), Bosch et al. (2012), and Paz (2014) find no or only limited evidence of a significant impact of import tariff reductions on informality in Brazil and Colombia. By 
contrast, Acosta and Montes-Rojas (2014) report an increase in labor informality in Argentina and Arias et al. (2013) and Dix-Carneiro and Kovak (2017) a similar effect following liberalization for Brazil and Mexico in the first case, and only for Brazil in the second case. Alemán-Castilla (2006), on the other hand, predicts a decrease in informality in Mexico. We argue that these heterogeneous results could be confounded by the different time spans of these studies, and by the different mechanisms uncovered by our analysis.

In fact, while the literature on trade and informality emphasizes different mechanisms to interpret the different empirical results, there is no study recognizing and estimating partial equilibrium mechanisms as a deviation from general equilibrium trends. Goldberg and Pavcnik (2003) focus on labor costs reductions due to increased foreign competition. Alemán-Castilla (2006) maintains that the reallocation of market shares and profits from the least productive to the most productive firms impacts negatively on the employment share of the informal sector. Similarly, Paz (2014) expects a reallocation of market shares between firms producing domestically and firms that export, which may impact on the share of informal workers. Bosch et al. (2012) and Acosta and MontesRojas (2014) investigate the greater access to imported capital goods that may increase productivity as a mechanism affecting the share of informal workers. Arias et al. (2013) highlight the increase in the opportunity cost of inactive individuals who could enter the labor force in informal or formal jobs depending on the entry costs. Finally, DixCarneiro and Kovak (2015) focus on the imperfect and slow factor adjustment associated with a trade liberalization episode. In their model, workers from the regions with larger tariff reductions spend less time in formal employment and transition mainly into the non-tradable sector, while workers from the non-tradable sector move slowly into informal employment.

The remainder of the paper is organized as follows. In Sect. 2, we describe the relationship between trade reforms and labor informality in Argentina through simple correlations, and we identify some of the mechanisms through which this relationship may operate. Section 3 presents our empirical strategy and the regression analysis to identify the effect of trade reforms on informality levels. Finally, Sect. 4 concludes.

\section{Trade reforms and informality: adjustment mechanisms}

In this section, we introduce the relationship between trade reforms and labor informality in Argentina and we identify some of the plausible mechanisms through which this relationship operates. This discussion illustrates the basic correlations that we study in detail in the econometric section below and it is intended to motivate the analysis. This first look at the data is based on a combination of tariff protection data with information from repeated cross sections of labor market surveys. We use the import tariffs data at the 3-digit ISIC classification (a total of 24 manufacturing sectors) compiled by Galiani and Porto (2010). The information about labor market outcomes comes from the Encuesta Permanente de Hogares (EPH), a periodical household and labor force survey with detailed information on labor market outcomes and individual and household characteristics. The overlap between the tariff data of Galiani and Porto (2010) and the labor 
Table 1 Tariffs and Informality. Source: Own elaboration based on EPH and Galiani and Porto (2010)

\begin{tabular}{|c|c|c|c|c|c|c|c|c|}
\hline \multirow[t]{3}{*}{ Years } & \multirow[t]{3}{*}{ Obs } & \multicolumn{2}{|c|}{ Tariffs } & \multicolumn{5}{|c|}{ Informality } \\
\hline & & \multirow[t]{2}{*}{ Avg. } & \multirow[t]{2}{*}{ Std. dev. } & \multirow[t]{2}{*}{ National } & \multicolumn{3}{|c|}{ Manufactures } & \multirow[t]{2}{*}{ Non-traded } \\
\hline & & & & & Total & Small industries & Large industries & \\
\hline 1980 & 1041 & 40.95 & 10.17 & 20.28 & 15.62 & 32.89 & 10.75 & 22.94 \\
\hline 1985 & 1048 & 31.55 & 6.37 & 23.19 & 17.80 & 33.76 & 12.61 & 25.54 \\
\hline 1986 & 1146 & 29.98 & 6.98 & 24.78 & 19.55 & 34.72 & 14.95 & 27.39 \\
\hline 1987 & 2346 & 29.39 & 7.55 & 26.93 & 21.12 & 41.80 & 14.61 & 29.71 \\
\hline 1988 & 2431 & 29.42 & 7.54 & 28.94 & 23.02 & 44.51 & 16.44 & 31.70 \\
\hline 1989 & 2459 & 31.65 & 8.03 & 29.30 & 24.51 & 43.92 & 18.37 & 31.32 \\
\hline 1990 & 1467 & 20.56 & 4.64 & 27.88 & 24.99 & 49.63 & 18.09 & 28.96 \\
\hline 1991 & 1583 & 15.33 & 5.51 & 33.05 & 29.63 & 55.09 & 21.49 & 34.35 \\
\hline 1992 & 1629 & 17.43 & 4.95 & 32.99 & 25.63 & 46.92 & 18.57 & 36.04 \\
\hline 1993 & 1634 & 21.34 & 6.27 & 33.74 & 26.81 & 48.36 & 19.99 & 36.51 \\
\hline 1994 & 1477 & 20.29 & 5.73 & 32.18 & 26.18 & 47.44 & 20.14 & 34.29 \\
\hline 1995 & 1345 & 18.52 & 3.91 & 34.42 & 26.86 & 47.04 & 21.71 & 36.65 \\
\hline 1996 & 1281 & 19.21 & 3.73 & 36.51 & 31.32 & 50.73 & 24.77 & 38.07 \\
\hline 1997 & 1379 & 19.23 & 3.98 & 38.26 & 30.94 & 55.85 & 23.35 & 40.43 \\
\hline 1998 & 1359 & 18.8 & 4.00 & 37.84 & 34.10 & 57.59 & 26.91 & 38.88 \\
\hline 1999 & 1230 & 18.6 & 3.96 & 38.65 & 34.49 & 56.33 & 27.85 & 39.68 \\
\hline 2000 & 1184 & 18.73 & 3.46 & 39.34 & 33.03 & 57.84 & 26.50 & 40.75 \\
\hline 2001 & 1085 & 25.51 & 5.28 & 39.07 & 34.01 & 54.68 & 29.20 & 40.34 \\
\hline
\end{tabular}

Number of observations correspond to wage employees in the manufacturing sector. Average tariff weighted by the employment level in each industry. The informality rate does not include the public sector, agricultural and mining sectors. To split industries into small and large, we use information from the EPH about the size of the firm where each worker is employed. This information is categorical in the survey, the categories being $1=1$ employee, $2=2$ to $5,3=5$ to $15 ; 4=16$ to $25 ; 5=26$ to $50 ; 6=51$ to $100 ; 7=101$ to $500 ; 8=501$ or more. We classify a firm as small when the size is 15 workers or less. We then define an industry as small when the share of workers employed in small firms is 0.5 or larger

market data from the EPH allows us to work with a long time series of 33 surveys spanning the $1980-2001$ period. $^{1}$

Table 1 reports yearly sample sizes (wage employees in the manufacturing sector) from EPH surveys, the average tariff and its standard deviation, and the average labor informality rate for manufactures, the non-tradable sector and the aggregate economy. ${ }^{2}$ We adopt the social protection-tax evasion definition of informality, which refers to the nature of the labor relationship between employer and employee rather than to characteristics of the worker or the firm (for instance, productivity). We classify a worker as informal if the firm does not pay the statutory payroll taxes and social insurance contributions based on his or her salary, which implies that the worker is not registered with the tax and social insurance administrations (we refer interchangeably to informal or unregistered workers). This implies that the worker does not receive the bundle of social insurance benefits financed by the State-basically, health insurance and the right to a

\footnotetext{
${ }^{1}$ We work with the October wave of the EPH in years 1980, 1985 and 1986, and with the May and October waves from 1987 to 2001.

2 We do not include public sector, agricultural and mining workers in our calculations, since the EPH is an urban survey without any coverage of rural areas. The sample also excludes self-employed workers because the EPH does not provide information to define their formality status and also because the mechanisms we analyze are relevant for employeremployee, rather than self-employment, labor relationships.
} 


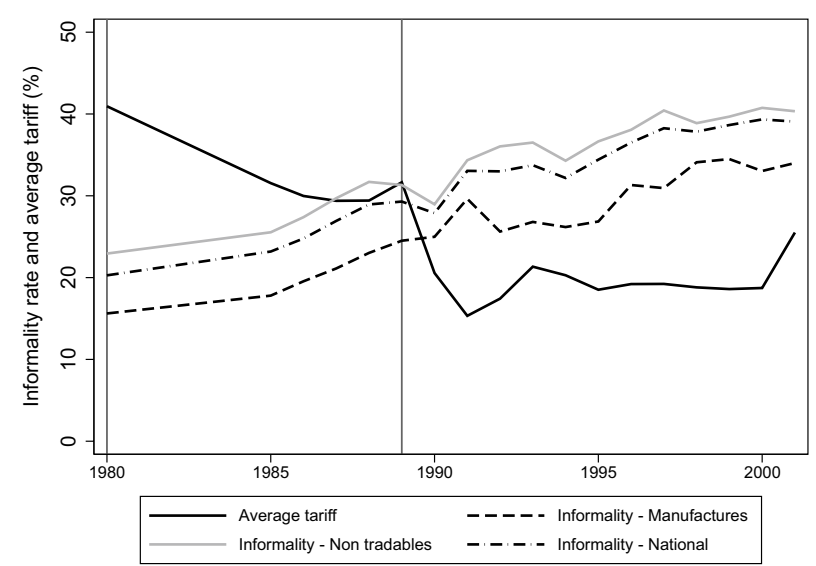

Fig. 1 Tariff reforms and informality (Source: Own elaboration based on EPH and Galiani and Porto (2010))

contributory old age employment-linked pension. This does not necessarily imply that labor informality is solely a unilateral decision of the worker or the firm. It can be an outcome from a bargaining process on employment characteristics, with associated costs (taxes and contributions for the firm, which potentially translate into lower wages for workers) and benefits (the social insurance package) (Galiani and Weinschelbaum 2011). There is a margin of adjustment because workers can have heterogeneous preferences in their valuation of these benefits, and firms can also face different costs associated, for instance, to their size through the enforcement of these labor market regulations (Kleven et al. 2009). The labor informality rate at the industry or aggregate level is simply the proportion of employees working in these conditions.

The simple descriptive statistics in Table 1 uncover the basic correlation that we study in this paper: while the average tariff fell 35 percent between 1980 and 2001, the average level of informality increased by 93 percent over the same period. We further explore this correlation in Fig. 1. During this period, there are two very noticeable episodes of tariff cuts. Protection was highest in 1980, with an average tariff of around 40 percent (with protection in some industries reaching 55 percent). The average tariff was cut by 10 percentage points between 1985 and 1989 and, in fact, the entire distribution of industry tariffs moved downward (the 75th percentile was, in general, below the 25th percentile of the first 2 years). ${ }^{3}$ After 1990, Argentina implemented a broad program of trade liberalization that included unilateral tariff reductions and the adoption of Mercosur, a regional trade agreement with neighboring countries Brazil, Paraguay and Uruguay in 1991. During this period, the mean tariff fell 10 additional percentage points, while tariff dispersion also declined.

The informality rate in manufactures, by contrast, exhibited an upward trend over time, more than doubling between 1980 and 2001. The greatest increase occurred in the 1980s, and it grew at a slower pace during the 1990s. The informality rate temporarily dropped from 1991 to 1994, a period of stabilization and growth following the

\footnotetext{
${ }^{3}$ As noted by Galiani and Porto (2010), this decade was also characterized by the non-tariff barriers, which we do not capture. Non-tariff barriers were, however, fully eliminated by the year 1988. We investigate the implications of this below. In 1989, there was also an increase in tariffs due to a hyperinflation crisis.
} 
hyperinflation episode of 1989-1991. In 1994, the most significant year in terms of labor and other market-oriented structural reforms in the economy, the informality rate returned to its increasing trend reaching peaks of 31 percent (in 1996) and 35 percent (in 1999). Within manufactures, informality was higher in small industries relative to large industries, with both showing increasing trends. ${ }^{4}$ Finally, note that the informality rate in the non-traded sector was higher than in the manufacturing sector, with a similar increasing trend over the period.

In the trade literature, firms typically respond to tariff cuts by reducing wages and by firing workers. An additional adjustment mechanism that we highlight in this paper is that firms may find it optimal to change the composition of their employment structure, with less formal jobs and more informal jobs. They can do so by firing "expensive" formal workers (because of payroll taxes and social insurance contributions) and hiring other workers informally (who, for a given set of characteristics, are cheaper from the point of view of the firm), or by colluding with their existing employees and re-negotiating existing employment relationships from formal to informal (Bérgolo and Cruces 2014). Additionally, informality can provide firms with more flexibility to adjust the labor force in the future as informal workers are not entitled to, for example, severance pay. Thus, increasing tax evasion in the form of unregistered or informal employment becomes a strategy for firms (and perhaps for workers, if the alternative is unemployment) to smooth the negative trade shock.

A fundamental premise of our analysis is that the correlation between tariffs and labor informality in the manufacturing sector combines partial and general equilibrium mechanisms. In partial equilibrium, when labor cannot reallocate across sectors, we should expect effects at the industry level. These effects are, thus, more easily pictured by comparing the cross-sectional relationship between changes in tariffs and changes in labor informality across industries. This relationship is plotted in Fig. 2. For all industries (panel A), this correlation is negative, so that industries exposed to larger tariff cuts experienced an increase in their labor informality rate. Furthermore, the correlation is much stronger among small-size industries (panel B) than among larger industries (panel C), where it actually vanishes. This indicates that the use of labor informality as an adjustment mechanism may differ according to the size of firms in each industry. The tax-evasion literature suggests that the detection technology used by the tax authority is a plausible explanation for these patterns.

To explore general equilibrium effects, we can look at conditional trends (Galiani and Porto 2010). To do this, we estimate a model using cross-section data where the dependent variable is the labor informality status of manufacturing workers, and the independent variables are their individual characteristics, industry tariffs, and industry and time indicators. These time dummies capture the level of informality at different periods of time, conditional on the other included covariates. In Fig. 3, we plot this conditional or residual informality rate on the average national tariff. In panel $\mathrm{A}$, the correlation

\footnotetext{
${ }^{4}$ We use information from the EPH about the size of the firm where each worker is employed. This information is categorical in the survey, the categories being $1=1$ employee, $2=2$ to $5,3=5$ to $15 ; 4=16$ to $25 ; 5=26$ to $50 ; 6=51$ to $100 ; 7=101$ to $500 ; 8=501$ or more. We classify a firm as small when the size is 15 workers or less. We then define an industry as small when the share of workers employed in small firms is 0.5 or larger. In our econometric analysis, we perform robustness tests on this size threshold.
} 


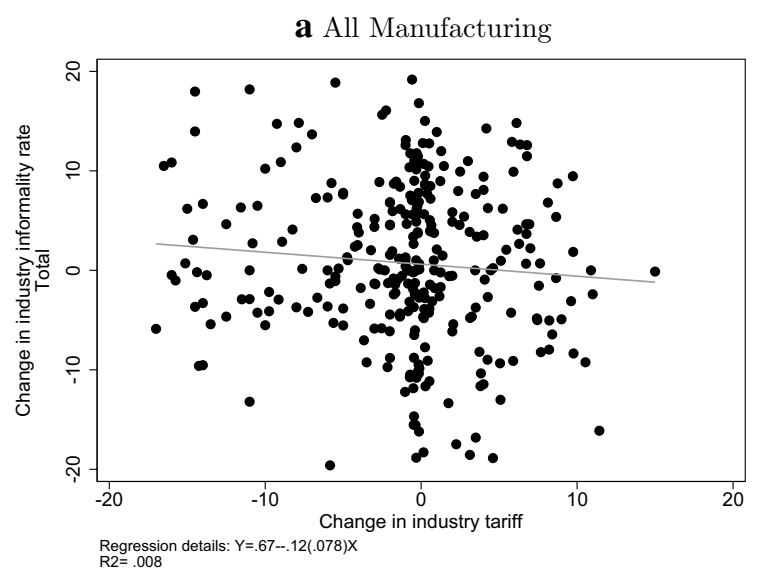

b Small Size Industries

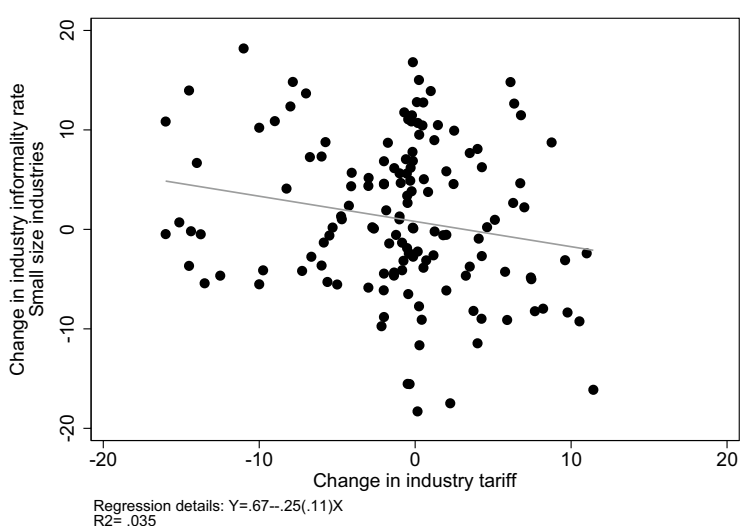

c Large Industries

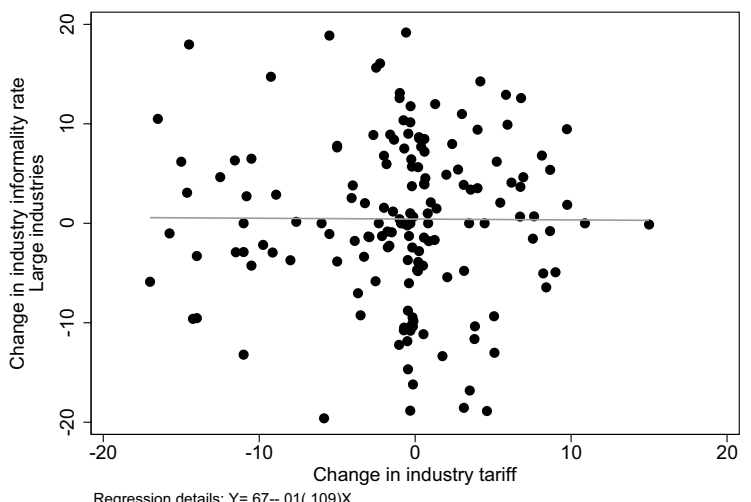

Regression details: $Y=.67-. .011(109) \mathrm{X}$
$\mathrm{R} 2=0$

Fig. 2 Changes in tariffs and in the informality rate cross-section. a All manufacturing. b Small-size industries. c Large industries. Source: Own elaboration based on EPH and Galiani and Porto (2010). To split industries into small and large, we use information from the EPH about the size of the firm where each worker is employed. This information is categorical in the survey, the categories being $1=1$ employee, $2=2$ to $5,3=5$ to 15 ; $4=16$ to $25 ; 5=26$ to $50 ; 6=51$ to $100 ; 7=101$ to $500 ; 8=501$ or more. We classify a firm as small when the size is 15 workers or less. We then define an industry as small when the share of workers employed in small firms is 0.5 or larger. In our econometric analysis, we perform robustness tests on this size threshold 


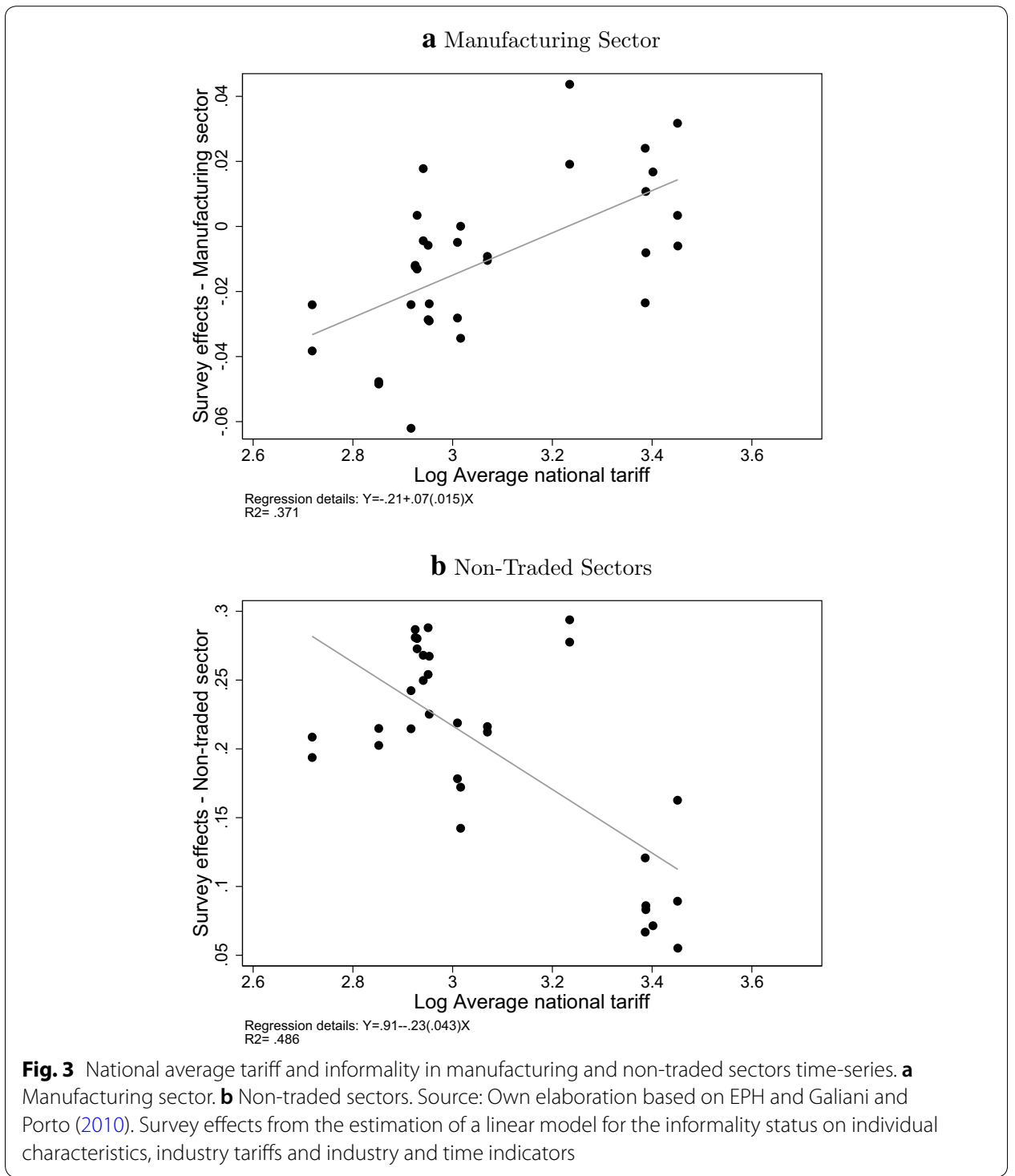

is positive, indicating that a reduction in labor informality over time occurred concurrently with the fall of the average national tariff once the effect of cross-industry tariff differences was accounted for.

In general equilibrium, informality in the non-traded sector can also be affected by trade policy. To show this, we estimate the conditional or residual informality rate for the non-traded sector, and we plot, in panel B of Fig. 3, the correlation with the average tariff. In this case, labor informality in the non-traded sector is negatively correlated with the average national tariff rate.

\section{Regression analysis}

In this section, we set up a formal regression analysis to explore the correlations established above. Our aims are to identify the causal impact of trade liberalization on informality and to disentangle the different mechanisms at work. We estimate the two-step 
empirical model of Galiani and Porto (2010) with an instrumental variables estimator. We first exploit the cross-sectional variation in tariffs and labor informality to estimate the partial equilibrium mechanisms or within industry effects. We then rely on our time series of cross-section data to estimate general equilibrium effects for the aggregate manufacturing and non-traded sectors.

\subsection{Cross-sectional mechanisms}

We begin with the cross-sectional analysis. Our empirical model is:

$$
y_{i j t}=\mathbf{x}_{i j t}^{\prime} \beta_{x}+\beta_{\tau} \ln \tau_{j t}+I_{j}+T_{t}+\varepsilon_{i j t},
$$

where $y_{i j t}$ is the informality status of individual $i$ employed in industry $j$ at time $t, \tau_{j t}$ is the tariff on industry $j$ at time $t$, and the vector $\mathbf{x}$ includes individual characteristics, such as gender, age, marital status, indicator variables for head of household and education, as well as household characteristics such as the number of children and household income (in equivalent-adult units). The baseline model also includes industry $I_{j}$ and time $T_{t}$ fixed effects.

Following the tax evasion literature discussed above, we expect the effect of trade policy changes to be different depending on firm size in each industry. Large firms are more visible and face a greater probability of detection. As a result, the labor force of a large firm will be mostly (or fully) formal. The opposite happens in small-size firms which face a lower probability of detection and, thus, may evade social insurance contributions to a greater extent. We work with two measures of industry size that arguably capture the tax evasion mechanism that we advocate. For definition 1, we use EPH data and calculate the shares of workers employed in small-size firms (firms with 15 workers or less) in each industry in 1980. The intuition is that industries where small firms are more prevalent than large firms will be less likely to be detected by the tax authorities. For definition 2 , we define indicator variables of industry size based on those shares. Concretely, an industry is defined as small when the share of workers in small firms is greater than the share of workers in large firms in 1980. According to this industry size definition, 12 out of the 24 industries were classified as small. ${ }^{5}$ We expand model (1) as follows:

$$
y_{i j t}=\mathbf{x}_{i j t}^{\prime} \beta_{x}+\beta_{\tau} \ln \tau_{j t}+\beta_{s \tau} S_{j} \ln \tau_{j t}+\beta_{s} S_{j}+I_{j}+T_{t}+\varepsilon_{i j t},
$$

where $S_{j}$ is the industry size variable, either the share of workers employed in small-size firms in industry $j$ (definition 1 ) or a small-industry dummy (definition 2), and $S_{j} \ln \tau_{j t}$ is an interaction term with the industry tariff. The coefficient of the interaction term, $\beta_{s \tau}$, is the part of the impact of trade on informal employment that depends on the initial share of small-size firms in the industry (definition 1) or the differential impact of trade on informal employment in initially small industries, relative to large industries (definition 2). We expect this interaction term to be negative.

We provide evidence in support of the estimation of differential impacts for small versus large size industries in Fig. 4. Previous to the major cut in tariffs between 1989 and 1990, the trend in the informality rate was similar in both groups of industries with a

\footnotetext{
${ }^{5}$ Appendix $\mathrm{C}$ presents results based on alternative cut-offs to define small and large size firms. Our results are robust to these alternative definitions.
} 


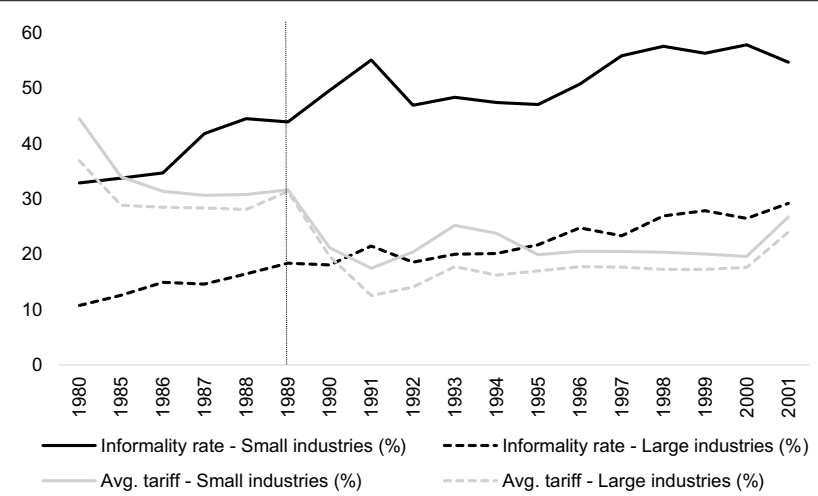

Fig. 4 Informality rate in small- versus large-size industries and tariff reforms. Source: Own elaboration based on EPH and Galiani and Porto (2010). Small-size industries using definition 2 (the share of workers in small firms is greater than the share of workers in large firms in 1980)

larger level for the small-size category. When the large tariff reduction took place, the informality rate increased comparatively more in small-size industries. We believe that the tax evasion arguments presented before explain the differential trend in labor informality observed in the figure.

This specification allows us to account for several confounding factors for the impacts of trade policy, $\beta_{\tau}$ and $\beta_{s \tau}$. Industry- and time fixed effects control for industry-specific characteristics and aggregate shocks related to business cycles and other policy changes. For instance, if the government raises tariffs during a recession and workers move from formality to informality, $\beta_{\tau}$ and $\beta_{s \tau}$ could be biased upward because of the business cycle effect. Time fixed effects also allow us to control for political economy changes related to the labor market, such as variations in tax regimes and in social insurance contributions, regulations regarding type of labor contracts, and so on. Similarly, unobserved industry characteristics that are time invariant, such as the ability to form a lobby, industry productivity or capital intensity, could affect industry tariffs and informal employment simultaneously. The inclusion of industry fixed effects controls these unobserved factors that could be correlated with tariffs and have an independent effect on informal employment.

In addition, our data span a long time series of active trade policy. A before-after comparison of a single episode of trade liberalization would be missing out the important fact that the comparison is between an initial pattern of trade protection and another one with lower protection, but not between autarky and free trade (Goldberg and Pavcnik 2007). As in Galiani and Porto (2010), our time series of cross-sections overcomes this limitation by allowing for the comparison of trends in trade reforms and those in the outcome variable of interest, labor informality.

Even in our setting, where we compare within industry changes along varying trends of trade liberalization, there might still remain certain omitted factors that can lead to biases. For instance, industry unionization and lobbying power can achieve lower tariff cuts and more rapid declines in informality. Alternatively, gains in productivity at the industry level may correlate with higher tariff cuts (because of lower costs of imported 
capital goods) as well as with larger declines in informality. ${ }^{6}$ To supplement our OLS results, we also explore instrumental variable models. We work with two instruments often used in the literature: the initial industry tariff and an industry weighted average of Argentina's trade partners exchange rates. More concretely, we interact industry tariffs in the first period (1980) with a three-category variable that captures three stages of Argentine trade policy, namely the initial period with high tariffs (years 1980-1985), the flat-tariff period of 1986-1989, and the last decade, from 1990 to 2001. A similar approach was proposed by Topalova (2010). The instrument $z^{1}$ is defined as:

$$
z_{j t}^{1}=\ln \tau_{j, 1980} * \text { Post }_{t}
$$

where $\tau_{j, 1980}$ is the initial sectoral tariff and Post $t_{t}$ is an indicator variable. The plausible validity of this instrument is illustrated in Fig. 5 . The top panel shows that import tariffs fell in all industries, while the bottom panel shows a differential pattern of tariff reduction across industries. Industries that traditionally received the highest level of protection experienced the most drastic reductions, while industries with the lowest tariff levels in 1980 faced the lowest reductions.

The second instrument $z^{2}$, the average exchange rate of main trading partners (Park et al. 2010; Brambilla et al. 2012), is defined as:

$$
z_{j t}^{2}=\sum_{c} e_{t}^{c} * \theta_{j, 1980}^{c}
$$

where $e_{t}^{c}$ is the exchange rate of country $c$ (relative to the Argentine peso) at time $t$ and $\theta_{j, 1980}^{c}$ is the share of country $c$ in Argentine imports of product $j$ in 1980. Given this share, a higher exchange rate of country $c$ will generate higher imports from this country. ${ }^{7}$ Tariffs may increase to protect industry $j$, or may fall to secure the gains from trade. This instrumental variable is thus based on the variation in the exchange rates of all trading partners-a change arguably exogenous to the model - and on each industry's exposure to those changes, given their initial share on Argentine imports of product $j$. By fixing the shares $\theta_{j, 1980}^{c}$ at the 1980 level, we seek to predetermine this value for all $t$, ensuring that tariff changes generated through exchange rates variations are exogenous.

Cross-section results are reported in Table 2 for the model that interacts industry tariffs with the share of small-size firms in each industry in 1980 (definition 1), and Table 3 for the model that interacts industry tariffs with an indicator variable of smallsize industry in 1980 (definition 2). In both tables, ordinary least squares (OLS) results are presented in panel A and instrumental variables (IV) results, in panel B. First-stage results of the IV models are reported in panel C. In all models, standard errors are clustered at the industry-year level.

In column 1, we estimate the model in (1), without interactions with industry size variables. The effect of the sectoral tariffs on labor informality at the industry level

\footnotetext{
${ }^{6}$ Acosta and Montes-Rojas (2014) report a lower impact of tariffs reduction on labor informality in industries that invest more during the 1992-2003 period in Argentina.

7 Since we need to build the instrument for the whole 1980-2001 period, and because of data limitations, we focus on Argentina's major trade partners, namely Brazil, Chile, the United States and the European Union. Imports value data come from UN Comtrade, and exchange rates data from the World Bank's World Development Indicators (WDI).
} 

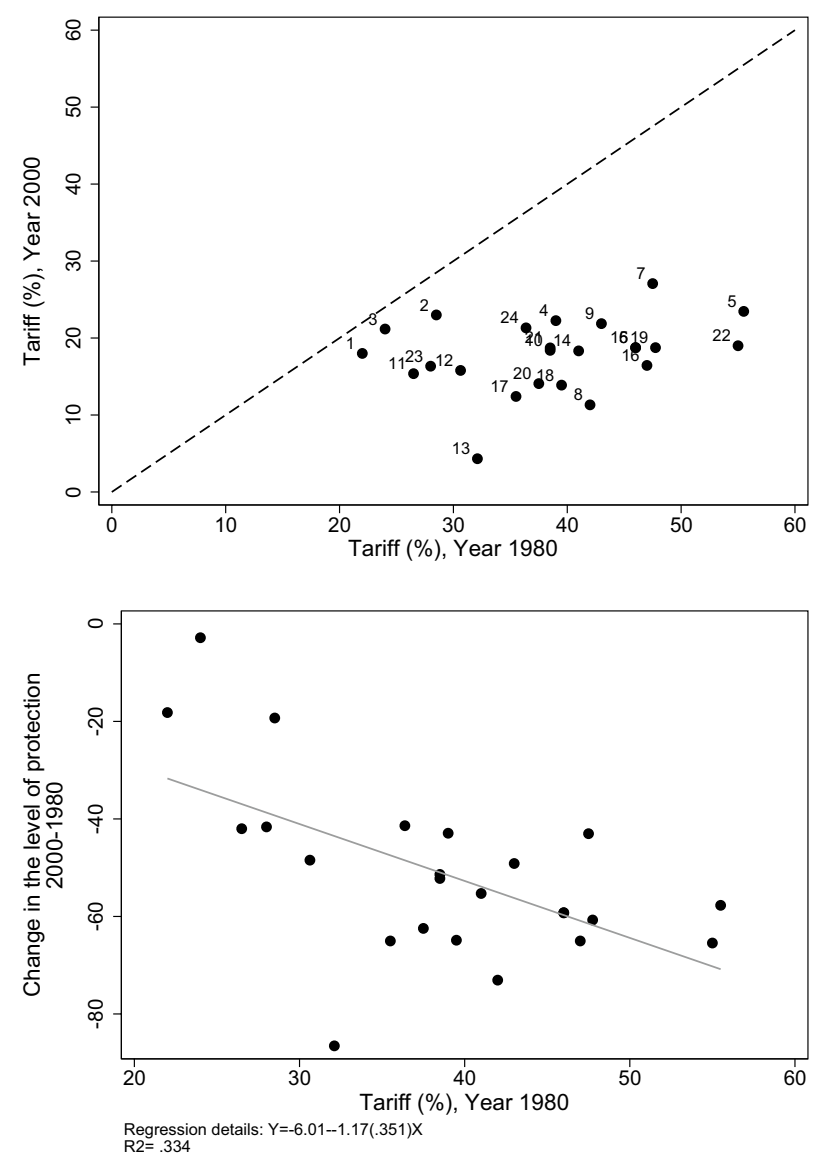

Fig. 5 Changes in tariff protection. Source: Own elaboration based on EPH and Galiani and Porto (2010). 1 Manufacture of food products, 2 Manufacture of beverages, 3 Manufacture of tobacco products, 4 Manufacture of textiles, 5 Manufacture of wearing apparel, except footwear, 6 Tanning and dressing of leather; manufacture of luggage, handbags, and saddlery and harness, 7 Manufacture of footwear, 8 Manufacture of wood and of products of wood and cork, except furniture, 9 Manufacture of furniture, 10 Manufacture of paper and paper products, 11 Publishing, printing and reproduction of recorded media, 12 Manufacture of chemicals and chemical products, 13 Manufacture of coke, refined petroleum products and nuclear fuel, 14 Manufacture of rubber, 15 Manufacture of plastics products, 16 Manufacture of glass and glass products, 17 Manufacture of other non-metallic mineral products, 18 Manufacture of basic metals, 19 Manufacture of fabricated metal products, except machinery and equipment, 20 Manufacture of machinery and equipment, except electric, 21 Manufacture of electrical machinery and apparatus n.e.c., 22 Manufacture of motor vehicles, trailers and semi-trailers, 23 Manufacture of medical, precision and optical instruments, 24 Manufacturing industries n.e.c

(within-industry effect) is indistinguishable from zero because potentially different industry responses cancel out, on average. In column 2, we allow for heterogeneous effects. In Table 2, we find a positive OLS effect of tariffs on informality but a negative interaction with industry size, as expected. In particular, as the share of small-size firms increases, the effect turns negative, indicating a within-industry increase in the informality rate when tariffs fall. As additional robustness tests, we include in column 3 the average industry wage as a control variable. Our estimated impacts are not affected significantly. This is consistent with the wage adjustment associated with an episode of trade liberalization being a general equilibrium mechanism that cannot be captured using the cross-sectional variation of the data. Finally, to account for other potential 
Table 2 Industry tariffs and informality interaction with share of small size-firms at the industry level in 1980 OLS and IV estimation

\begin{tabular}{|c|c|c|c|c|}
\hline $\begin{array}{l}\text { Dep. var.: informality } \\
\text { status of workers }\end{array}$ & (1) & $(2)$ & (3) & (4) \\
\hline \multicolumn{5}{|l|}{ A) OLS } \\
\hline Log of tariffs & $0.011[0.015]$ & $0.044[0.018]^{* *}$ & $0.043[0.018]^{* *}$ & $0.049[0.019]^{* *}$ \\
\hline Log of tariffs*S & & $-0.143[0.037]^{* * *}$ & $-0.144[0.037]^{* * *}$ & $-0.165[0.040]^{* * *}$ \\
\hline Observations & 26795 & 26795 & 26795 & 26795 \\
\hline $\mathrm{R} 2$ & 0.18 & 0.18 & 0.18 & 0.18 \\
\hline \multicolumn{5}{|c|}{ B) IV-Second-stage results: informality } \\
\hline Log of tariffs & $-0.178[0.208]$ & $0.087[0.083]$ & $0.091[0.083]$ & $0.1[0.084]$ \\
\hline Log of tariffs*S & & $-0.202[0.054]^{* * *}$ & $-0.2[0.055]^{* * *}$ & $-0.257[0.065]^{* * *}$ \\
\hline Observations & 26795 & 26795 & 26795 & 26795 \\
\hline \multicolumn{5}{|l|}{ C) First-stage results: tariffs } \\
\hline \multicolumn{5}{|l|}{ Log of tariffs } \\
\hline$z^{1}$ & $-0.037[0.066]$ & $-0.168[0.080]^{* *}$ & $-0.168[0.080]^{* *}$ & $-0.158[0.081]^{*}$ \\
\hline$z * S$ & & $0.06[0.020]^{* * *}$ & $0.06[0.020]^{* * *}$ & $0.061[0.022]^{* * *}$ \\
\hline$z^{2}$ & $-0.147[0.112]$ & $-0.198[0.107]^{*}$ & $-0.198[0.107]^{*}$ & $-0.201[0.111]^{*}$ \\
\hline$z^{2 * S}$ & & $0.31[0.220]$ & $0.31[0.220]$ & $0.315[0.221]$ \\
\hline$R^{2}$ & 0.74 & 0.74 & 0.74 & 0.74 \\
\hline \multicolumn{5}{|l|}{ Log of tariffs*S } \\
\hline$z^{1}$ & & $-0.05[0.024]^{* *}$ & $-0.05[0.024]^{* *}$ & $-0.045[0.024]^{*}$ \\
\hline$z^{1 * S}$ & & $-0.076[0.009]^{* * *}$ & $-0.076[0.009]^{* * *}$ & $-0.073[0.009]^{* * *}$ \\
\hline$z^{2}$ & & $0.024[0.031]$ & $0.022[0.031]$ & $0.018[0.031]$ \\
\hline$z^{2 * S}$ & & $-0.145[0.080]^{*}$ & $-0.147[0.080]^{*}$ & $-0.145[0.082]^{*}$ \\
\hline$R^{2}$ & & 0.99 & 0.99 & 0.99 \\
\hline Kleibergen-Papp Wald F & 1.09 & 2.38 & 2.38 & 2.08 \\
\hline $\begin{array}{l}\text { Anderson-Rubin Wald F test } \\
\text { ( } p \text {-value) }\end{array}$ & 0.0358 & 0.0003 & 0.0004 & 0.0000 \\
\hline
\end{tabular}

Cross-section panel regressions of sectoral informality on industry tariffs. Industry size $S$ is defined based on the share of small firms in each industry in 1980. In panels B and C, $z^{1}$ is the instrument defined using tariffs in $1980 ; z^{2}$ is the instrument based on exchange rates of main partners. Robust standard errors clustered at the industry-year level in brackets. The Stock-Yogo critical values for a 5\% and 10\% maximal IV relative bias are 19.93 and 11.59 in column (1) and 11.04 and 7.56 in columns (2) to (4) respectively

*** Significant at 1\%

** Significant at 5\%

* Significant at 10\%

confounding factors that might be driving the results, we include initial industry characteristics, namely the share of skilled workers and the size of the labor force in 1980, interacted with the variable Post $_{t}$ (which captures the trade policy stages). The results in column 4 indicate that tariff reductions still lead to increases in labor informality in industries with an initially large share of small-size firms. The magnitude of the effects is (in absolute value) larger than before, indicating that confounding factors, if any, were weakening the estimated impacts.

For further robustness analysis of our estimates, we discuss next the IV results. In panel C of Table 2, we evaluate the first-stage results. The instruments behave relatively well in terms of statistical significance, specially when we include an interaction term with a industry size variables. However, using the Kleibergen-Paap Wald test and the Stock-Yogo critical values, we cannot reject the hypothesis that the instruments are 
Table 3 Industry tariffs and informality interaction with indicator variable of small-size industry in 1980 OLS and IV estimation

\begin{tabular}{|c|c|c|c|c|}
\hline $\begin{array}{l}\text { Dep. var.: informality } \\
\text { status of workers }\end{array}$ & (1) & $(2)$ & (3) & (4) \\
\hline \multicolumn{5}{|l|}{ A) OLS } \\
\hline Log of tariffs & $0.011[0.015]$ & $0.02[0.015]$ & $0.02[0.015]$ & $0.023[0.015]$ \\
\hline Log of tariffs*s & & $-0.038[0.018]^{* *}$ & $-0.039[0.018]^{* *}$ & $-0.045[0.019]^{* *}$ \\
\hline Observations & 26795 & 26795 & 26795 & 26795 \\
\hline $\mathrm{R} 2$ & 0.18 & 0.18 & 0.18 & 0.18 \\
\hline \multicolumn{5}{|c|}{ B) IV-Second-stage results: informality } \\
\hline Log of tariffs & $-0.178[0.208]$ & $-0.021[0.065]$ & $-0.019[0.064]$ & $-0.02[0.067]$ \\
\hline Log of tariffs*S & & $-0.086[0.029]^{* * *}$ & $-0.086[0.029]^{* * *}$ & $-0.105[0.037]^{* * *}$ \\
\hline Observations & 26795 & 26795 & 26795 & 26795 \\
\hline \multicolumn{5}{|l|}{ C) First-stage results: tariffs } \\
\hline \multicolumn{5}{|l|}{ Log of tariffs } \\
\hline$z^{1}$ & $-0.037[0.066]$ & $-0.141[0.068]^{* *}$ & $-0.142[0.068]^{* *}$ & $-0.13[0.072]^{*}$ \\
\hline$z^{1 *}$ & & $0.035[0.010]^{* * *}$ & $0.035[0.010]^{* * *}$ & $0.036[0.011]^{* * *}$ \\
\hline$z^{2}$ & $-0.147[0.112]$ & $-0.225[0.108]^{* *}$ & $-0.226[0.108]^{* *}$ & $-0.229[0.112]^{* *}$ \\
\hline$z^{2 * S}$ & & $0.255[0.084]^{* * *}$ & $0.255[0.084]^{* * *}$ & $0.255[0.084]^{* * *}$ \\
\hline$R^{2}$ & 0.74 & 0.75 & 0.75 & 0.75 \\
\hline \multicolumn{5}{|l|}{ Log of tariffs*S } \\
\hline$z^{1}$ & & $-0.059[0.035]^{*}$ & $-0.061[0.035]^{*}$ & $-0.028[0.034]$ \\
\hline$z^{1 * S}$ & & $-0.082[0.006]^{* * *}$ & $-0.081[0.006]^{* * *}$ & $-0.078[0.007]^{* * *_{1}}$ \\
\hline$z^{2}$ & & $-0.023[0.064]$ & $-0.028[0.064]$ & $-0.043[0.068]$ \\
\hline$z^{2 * S}$ & & $0.051[0.066]$ & $0.047[0.066]$ & $0.05[0.064]$ \\
\hline$R^{2}$ & & 0.99 & 0.99 & 0.99 \\
\hline Kleibergen-Papp Wald F & 1.09 & 4.52 & 4.52 & 4.02 \\
\hline $\begin{array}{l}\text { Anderson-Rubin Wald F test } \\
\text { (p-value) }\end{array}$ & 0.0358 & 0.0136 & 0.0133 & 0.0056 \\
\hline
\end{tabular}

Cross-section panel regressions of sectoral informality on industry tariffs. Industry size $S$ is a dummy variable indicating small industries in 1980. In panels B and $C_{1} z^{1}$ is the instrument defined using tariffs in 1980; $z^{2}$ is the instrument based on exchange rates of main partners. Robust standard errors clustered at the industry-year level in brackets. The Stock-Yogo critical values for a 5\% and 10\% maximal IV relative bias are 19.93 and 11.59 in column (1) and 11.04 and 7.56 in columns (2) to (4) respectively

*** Significant at $1 \%$

** Significant at $5 \%$

* Significant at $10 \%$

weak. ${ }^{8}$ Despite this result, the Anderson-Rubin test does reject the null hypothesis that the instruments are irrelevant in the second stage (when omitting tariffs). Consequently, while the IV results can still show some biases, we believe they are still useful in better establishing a link between tariffs and informality. Turning back to the second-stage regressions in panel B, we confirm the results in columns 1-4. If anything, the IV results appear stronger in magnitude.

The lack of an effect in large industries or the reduction in the informality rate reported in Table 2 can be explained by tax evasion arguments: large firms face a high probability of detection and do not resort to labor informality as an adjustment mechanism. An

\footnotetext{
${ }^{8}$ Note that while the Stock-Yogo critical values are not valid under clustered standard errors, it is still customary to use them with the Kleibergen-Paap tests. Montiel Olea and Pflueger (2013) introduce a test that is valid for non-iid errors, but which is only applicable with one endogenous regressor.
} 
additional explanation can be found in heterogeneous firms models of trade. Exporting firms are larger and more productive than domestically oriented firms (Bernard and Jensen 1995). Thus, large industries are expected to have a larger participation of exporting firms. With trade liberalization, these firms can gain access to new markets and expand, reducing the participation of informal labor. This behavior may neutralize any increase in informal employment by large firms producing for the domestic market. Bustos (2011) provides evidence on the expansion of the exporting segment in Argentine industries during 1992-1996 in the context of a regional trade liberalization episode (Mercosur).

For completeness, we end this section with a brief discussion of the model that interacts industry tariffs with an indicator variable of small-size industry. These are results are reported in Table 3. As it can be seen, the estimates in column 1-4 behave as before, qualitatively. This provides additional support to the overall evaluation of the cross-section results.

\subsection{General equilibrium mechanisms}

We now use the time series variability in the data to look at general equilibrium effectsvia labor reallocation and wage adjustment as well as via firm entry and exit-that cannot be captured with cross-sectional data. In particular, we investigate the aggregate effect of tariffs on both manufacturing and non-tradable sectors. We study these effects with the strategy proposed by Galiani and Porto (2010). The general idea is that the level of protection of a country (i.e., the average national tariff) has general equilibrium impacts on informality. However, the economy is not fully flexible in the short-run, so that while there is an underlying trend in informality that depends on the trend in average protection, there are short-run departures from this trend (e.g., the within industry results of previous sections). Conceptually, the idea of Galiani and Porto (2010) is to control those short-run departures of the trend to extract the general equilibrium effect of tariffs. In a first step, we estimate the model we used to analyze the cross-sectional mechanisms (model (2)) and we recover the time fixed effects. We interpret the time fixed effects as measures of the residual informality rate at time $t$ once all the cross-section covariates used in model (2) are accounted for, i.e., the part of the time-trend that is not correlated with individual characteristics and specially with industry tariffs. Then, in a second step, we regress the residual informality rate on the average national tariff of the economy weighted by the participation of each industry in total employment:

$$
\hat{T}_{t}=\mathbf{m}_{t}^{\prime} \alpha_{m}+\alpha_{\tau} \ln \tau_{t}+v_{t},
$$

where $\mathbf{m}$ is a vector of controls. Because the dependent variable in this second stage is estimated, we use weighted least squares with weights given by the inverse of the estimates of the variance of the time fixed effects from the first stage.

Results are provided in Table 4 (using alternatively industry size definition 1 and industry size definition 2 in the first step of the procedure (model (2))). The controls included in $\mathbf{m}$ in (5) are the ratio of the labor force in tradable to non-tradable sectors, the average educational level of the labor force and the proportion of small firms in each sector, and a linear time trend. Columns 1-3 show the OLS coefficients. The average tariff is positively associated with the labor informality trend in the manufacturing sector. 
Table 4 Average tariff and informality in the manufacturing sector OLS and IV estimation

\begin{tabular}{|c|c|c|c|c|c|c|}
\hline \multirow{2}{*}{$\begin{array}{l}\text { Dep. var.: } \\
\text { residual } \\
\text { informality rate }\end{array}$} & \multicolumn{3}{|l|}{ OLS } & \multicolumn{3}{|l|}{ IV } \\
\hline & (1) & (2) & (3) & (4) & (5) & (6) \\
\hline \multicolumn{7}{|c|}{ Definition 1: share of small-size firms in industry } \\
\hline Log tariff & $0.19[0.012]^{* * * *}$ & $0.192[0.012]^{* * * *}$ & $0.192[0.0130]^{* * *}$ & $0.147[0.027]^{* * *}$ & $0.140[0.037]^{* * * *}$ & $0.144[0.0343]^{* * *}$ \\
\hline Observations & 32 & 32 & 32 & 32 & 32 & 32 \\
\hline$R^{2}$ & 0.91 & 0.91 & 0.918 & & & \\
\hline \multicolumn{7}{|l|}{ First stage result } \\
\hline Average $z^{2}$ & & & & $-0.398[0.094]^{* * *}$ & $-0.435[0.117]^{* * *}$ & $-0.441[0.119]^{* * *}$ \\
\hline Observations & & & & 32 & 32 & 32 \\
\hline$R^{2}$ & & & & 0.72 & 0.74 & 0.74 \\
\hline \multicolumn{7}{|c|}{ Definition 2: indicator of small-size industry } \\
\hline Log tariff & $0.121[0.012]^{* * * *}$ & $0.12[0.012]^{* * * *}$ & $0.120[0.0128]^{* * *}$ & $0.077[0.022]^{* * * *}$ & $0.064[0.036]^{*}$ & $0.0659[0.0350]^{*}$ \\
\hline Observations & 32 & 32 & 32 & 32 & 32 & 32 \\
\hline$R^{2}$ & 0.92 & 0.92 & 0.93 & & & \\
\hline \multicolumn{7}{|l|}{ First stage result } \\
\hline Average $z^{2}$ & & & & $-0.416[0.097]^{* * * *}$ & $-0.434[0.120]^{* * *}$ & $-0.437[0.122]^{* 3 *}$ \\
\hline Observations & & & & 32 & 32 & 32 \\
\hline$R^{2}$ & & & & 0.73 & 0.74 & 0.75 \\
\hline \multicolumn{7}{|l|}{ Control variables } \\
\hline $\begin{array}{l}\text { Log relative } \\
\text { supply }\end{array}$ & Yes & Yes & Yes & Yes & Yes & Yes \\
\hline $\begin{array}{l}\text { Educational level } \\
\text { of the labor } \\
\text { force }\end{array}$ & Yes & Yes & Yes & Yes & Yes & Yes \\
\hline $\begin{array}{l}\text { Fraction of small } \\
\text { firms }\end{array}$ & No & Yes & Yes & No & Yes & Yes \\
\hline $\begin{array}{l}\text { Linear time } \\
\text { trend }\end{array}$ & No & No & Yes & No & No & Yes \\
\hline
\end{tabular}

Time series regressions of residual informality on the national average tariff. Robust standard errors clustered at the year level in brackets. Average $z^{2}$ is the average of the instrument based on exchange rates of main partners weighted by the participation of each industry in total employment

*** Significant at $1 \%$

* Significant at $10 \%$

In columns 4-6, we report the IV estimates, where the instrument is the average of the exchange rate of major trade partners in each period, weighted by the participation of each industry in total employment. ${ }^{9}$ The first-stage results show that this instrument is statistically significant. IV estimates from the second stage show that the average tariff impacts positively on the labor informality trend of the manufacturing sector (i.e., a reduction in tariffs reduces labor informality), after controlling for the structure of sectoral protection and allowing for general equilibrium adjustments. Our estimates range between 0.06 and 0.15 , indicating a reduction in the labor informality rate of 0.6 to 1.5 percentage point for each $10 \%$ reduction in the national average tariff.

We can interpret these results as follows. In the cross-section, inter-industry differences in tariff cuts increase labor informality being the effect differentially stronger in industries with a larger share of small-size firms. This is consistent with our hypothesis that the loss of profitability of manufacturing firms induces them to decrease their

${ }^{9}$ As before, the instrumental variables in the first step (model (2)) are $z^{1}, z^{2}$ and their interactions with indicator variables of initial size of industries. 


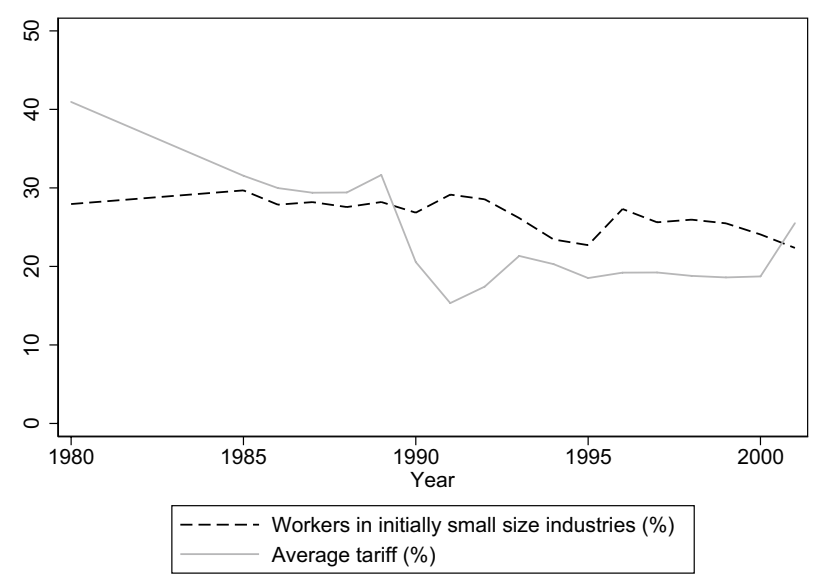

Fig. 6 Share for workers in initially small-size industries and average tariff. Source: Own elaboration based on EPH and Galiani and Porto (2010). Small-size industries using definition 2 (the share of workers in small firms is greater than the share of workers in large firms in 1980)

formal-informal employment combination so that informality increases. Given this structure of sectoral protection, however, aggregate labor informality in manufactures declines with the fall in the national average tariff. This is because of two reasons. First, the outflow of workers and the resulting wage adjustment can make formality cheaper. Second, foreign competition can lead to firm exit and these are low productivity and probably low size firms which employ more informal workers. ${ }^{10}$ We provide evidence of this channel in Fig. 6 . The share of workers in initially small-size industries declined over time jointly with average tariff. Considering that the share of informal workers was always larger in small-size industries (Table 1), firm exit can help explain the reduction in aggregate labor informality in the manufacturing sector. In terms of Fig. 1, all this evidence shows that the trend in labor informality in the manufacturing sector would have been steeper in the absence of trade liberalization.

With a similar reasoning, the non-traded sector may also be affected by the changes in average protection in manufactures. To explore this, we run the first-step regressions (model (2)) using workers in the non-traded sector (thus excluding the trade policy variables on the right-hand side). In the second step, we regress the residual average informality rate (i.e., the time fixed effects recovered from the first stage) on the average national tariff. The results from these estimations are presented in Table 5. Both the OLS (columns 1-3) and IV (columns 4-6) estimates reveal that aggregate trade protection affects negatively and significantly the labor informality trend in the non-traded sectori.e., the fall in tariffs increased labor informality in this sector. In particular, the IV estimate is around -0.11 and -0.13 , indicating an increase in the informality rate of the non-traded sector of around 1 percentage point for each $10 \%$ reduction in the national average tariff. This can happen if, for instance, workers that are fired from manufactures because of the lower tariffs are absorbed in the non-traded sector as informal employees. In addition, informality can increase if the non-traded sector expands and small firms

${ }^{10}$ Sánchez and Butler (2004) present evidence on the exit of the least productive manufacturing firms in Argentina during 1990-2001 as a consequence of tariff reductions. 
Table 5 Average tariff and informality in the non-traded sector OLS and IV estimation

\begin{tabular}{|c|c|c|c|c|c|c|}
\hline \multirow{2}{*}{$\begin{array}{l}\text { Dep. var.: } \\
\text { residual } \\
\text { informality } \\
\text { rate }\end{array}$} & \multicolumn{3}{|l|}{ OLS } & \multicolumn{3}{|l|}{ IV } \\
\hline & (1) & $(2)$ & (3) & (4) & $(5)$ & (6) \\
\hline \multicolumn{7}{|c|}{ Definition 1: share of small-size firms in industry } \\
\hline Log tariff & $-0.03[0.011]^{* *}$ & $-0.021[0.010]^{* *}$ & $-0.0215[0.00918]^{* *}$ & $-0.113[0.036]^{* * *}$ & $-0.133[0.063]^{*}$ & $-0.130[0.0630]^{*}$ \\
\hline Observations & 32 & 32 & 32 & 32 & 32 & 32 \\
\hline$R^{2}$ & 0.98 & 0.98 & 0.982 & & & \\
\hline \multicolumn{7}{|l|}{ First stage result } \\
\hline Average $z^{2}$ & & & & $-0.448[0.117]^{* * *}$ & $-0.376[0.129]^{* * *}$ & $-0.379[0.131]^{* * * *}$ \\
\hline Observations & & & & 32 & 32 & 32 \\
\hline$R^{2}$ & & & & 0.76 & 0.79 & 0.79 \\
\hline \multicolumn{7}{|c|}{ Definition 2: indicator of small-size industry } \\
\hline Log tariff & $-0.03[0.011]^{* *}$ & $-0.021[0.010]^{* *}$ & $-0.0215[0.00918]^{* *}$ & $-0.113[0.036]^{* * *}$ & $-0.133[0.063]^{*}$ & $-0.130[0.0630]^{*}$ \\
\hline Observations & 32 & 32 & 32 & 32 & 32 & 32 \\
\hline$R^{2}$ & 0.98 & 0.98 & 0.982 & & & \\
\hline \multicolumn{7}{|l|}{ First stage result } \\
\hline Average $z^{2}$ & & & & $-0.448[0.117]^{* * *}$ & $-0.376[0.129]^{* * *}$ & $-0.379[0.131]^{* * *}$ \\
\hline Observations & & & & 32 & 32 & 32 \\
\hline$R^{2}$ & & & & 0.76 & 0.79 & 0.79 \\
\hline \multicolumn{7}{|l|}{ Control variables } \\
\hline $\begin{array}{l}\text { Log relative } \\
\text { supply }\end{array}$ & Yes & Yes & Yes & Yes & Yes & Yes \\
\hline $\begin{array}{l}\text { Educational } \\
\text { level of the } \\
\text { labor force }\end{array}$ & Yes & Yes & Yes & Yes & Yes & Yes \\
\hline $\begin{array}{l}\text { Fraction of smal } \\
\text { firms }\end{array}$ & I No & Yes & Yes & No & Yes & Yes \\
\hline $\begin{array}{l}\text { Linear time } \\
\text { trend }\end{array}$ & No & No & Yes & No & No & Yes \\
\hline
\end{tabular}

Time series regressions of residual informality on the national average tariff. Robust standard errors clustered at the year level in brackets. Average $z^{2}$ is the average of the instrument based on exchange rates of main partners weighted by the participation of each industry in total employment

*** Significant at $1 \%$

** Significant at 5\%

* Significant at 10\%

enter the market. In terms of Fig. 1, the trend in labor informality in the non-tradables sector would have been flatter in the absence of trade liberalization episodes.

\subsection{Additional supporting evidence: wage adjustment}

In this section, we study the role of wage adjustment to provide additional supporting evidence for our results and for the mechanisms we posit. To explore whether sectoral tariffs affect the wage differential between formal and informal workers in the the crosssection, we estimate a series of models of the form:

$$
\begin{aligned}
\ln w_{i j t}= & \mathbf{x}_{i j t}^{\prime} \beta_{x}+\beta_{d} d_{i j t}+\beta_{\tau} \ln \tau_{j t}+\beta_{d \tau} d_{i j t} \ln \tau_{j t} \\
& +\beta_{s d \tau} d_{i j t} \ln \tau_{j t} S_{j}+\beta_{s} S_{j}+I_{j}+T_{t}+\varepsilon_{i j t}
\end{aligned}
$$


where $\ln w_{i j t}$ is the logarithm of the hourly wage for individual $i$ employed in industry $j$ in $t, \tau_{j t}$ is the tariff on industry $j$ at $t$, and the vector $\mathbf{x}$ includes the same set of individual characteristics as model (1). The variable $d_{i j t}$ indicates the labor informality status of worker $i$ in industry $j$ at time $t$, and $S_{j}$ is the industry size indicator (either the share of workers in small-size firms or a dummy for small-size industry). Here, the parameters of interest are $\beta_{d \tau}$ and $\beta_{s d \tau}$, which capture the differential impact of tariff changes on the wage of workers with varying informality status at different industry sizes. $I_{j}$ and $T_{t}$ are industry and time fixed effects.

We estimate model (6) by OLS and IV using $z_{j t}^{1}$ and $z_{j t}^{2}$ to instrument sectoral tariffs, as before. ${ }^{11}$ Table 6 presents the OLS and IV estimation results. Panel A reports estimates when using the share of small-size firms as industry-size variable (definition 1), while panel B reports results when interacting industry tariffs with an indicator variable for small-size industry (definition 2). Industry tariffs have no effects on the within-industry wage differential between informal and formal workers at the usual significance levels, regardless the estimation method and regardless the inclusion of heterogenous effects by industry size. This finding is consistent with labor informality being the within-industry mechanism of adjustment when labor cannot reallocate across sectors.

To study the general equilibrium adjustment, we use the identification strategy based on the time-series variability of tariff data presented before. In a first stage, we estimate a wage regression including the interaction between $d_{i j t}$ and time effects $T_{t}$ as additional control variables. The coefficients associated with these interaction terms, $\widehat{\beta}_{d t}$, capture the residual wage differential between informal and formal workers in each time period. We estimate this first stage separately for the manufacturing sector (controlling for the sectoral structure of tariffs) and for the non-tradable sector. In the second stage, we use the time dimension of the data and propose a model for the wage differential between informal and formal workers in each time period in both sectors (estimated from the first stage) on the average national tariff. The reason to group the estimated effects from both sectors is that in general equilibrium we expect the wage adjustment to occur for the whole economy, since workers can move across sectors. We estimate models of the form:

$$
\hat{\beta}_{d t}=\mathbf{x}_{t}^{\prime} \alpha_{x}+\alpha_{\tau} \ln \tau_{t}+v_{t},
$$

where vector $\mathbf{x}$ includes the ratio of the labor force in the manufacturing to non-tradable sectors, the ratio of formal and informal labor force in the whole economy, their educational level, and a linear time trend. We obtain the coefficients through weighted least squares, using the inverse of the estimates of the variance of the effects from the first stage as weights.

Table 7 presents our OLS and IV results, where we instrument for the sectoral structure of protection in the first stage using $z_{j t}^{1}$ and $z_{j t}^{2}$, and for the national tariff in the

\footnotetext{
${ }_{11}$ We also explore instrumental variable models where the informality $d_{i j t}$ is instrumented as well. Informality can be endogenous if a low formal wage, for instance, creates a preference for informal employment or if unobserved factors such as labor perspectives or job attributes are present. The results appear in Appendix A. In addition, we replicate the procedure proposed by Paz (2014). Paz estimates a switching regression model where informal and formal wages are modeled separately as a function of tariffs and the inverse Mills ratio obtained from the estimation of a model for the probability of informal employment. We apply the same methodology and obtain the same conclusion we report in this sub-section. These results are reported in Appendix B.
} 
Table 6 Industry tariffs and wage differentials formal and informal workers OLS and IV estimation

\begin{tabular}{|c|c|c|c|c|}
\hline \multirow{2}{*}{$\begin{array}{l}\text { Dep. var.: logarithm of workers' } \\
\text { hourly wages }\end{array}$} & \multicolumn{2}{|l|}{ OLS } & \multicolumn{2}{|l|}{ IV } \\
\hline & (1) & (2) & (3) & (4) \\
\hline \multicolumn{5}{|c|}{ A) Definition 1: share of small-size firms in industry } \\
\hline$=1$ if informal & $-0.153[0.095]$ & $-0.112[0.097]$ & $-0.082[0.183]$ & $-0.129[0.193]$ \\
\hline Log of tariffs & $0.034[0.022]$ & $0.037[0.022]^{*}$ & $0.065[0.069]$ & $0.02[0.063]$ \\
\hline$=1$ if informal ${ }^{*}$ Log of tariffs & $-0.005[0.029]$ & $-0.025[0.033]$ & $-0.368[0.216]^{*}$ & $-0.24[0.182]$ \\
\hline$=1$ if informal* ${ }^{*} \log$ of tariffs*S & & $0.015[0.018]$ & & $0.01[0.023]$ \\
\hline Observations & 20661 & 20661 & 20661 & 20661 \\
\hline$R^{2}$ & 0.38 & 0.38 & & \\
\hline \multicolumn{5}{|c|}{ B) Definition 2: indicator of small-size industry } \\
\hline$=1$ if informal & $-0.153[0.095]$ & $-0.122[0.094]$ & $-0.082[0.183]$ & $-0.204[0.222]$ \\
\hline Log of tariffs & $0.034[0.022]$ & $0.036[0.022]^{*}$ & $0.065[0.069]$ & $0.017[0.065]$ \\
\hline$=1$ if informal* ${ }^{*}$ og of tariffs & $-0.005[0.029]$ & $-0.021[0.030]$ & $-0.368[0.216]^{*}$ & $-0.239[0.193]$ \\
\hline$=1$ if informal* ${ }^{*} \log$ of tariffs ${ }^{*} S$ & & $0.009[0.009]$ & & $0.01[0.011]$ \\
\hline Observations & 20661 & 20661 & 20661 & 20661 \\
\hline$R^{2}$ & 0.38 & 0.38 & & \\
\hline
\end{tabular}

Cross-section panel regressions of formal-informal wage differential and industry tariffs. Industry size $S$ defined based on the share of small firms in each industry in 1980 (panel A) and as a dummy indicating small industries in 1980 (panel B). Robust standard errors clustered at the industry-year level in brackets

* Significant at $10 \%$

second stage using the average of the exchange rate of major trade partners in each period, weighted by the participation of each industry in total employment. Panel A shows the results obtained when the first stage allows for heterogenous impact by industry size using definition 1 , while panel B uses definition 2 . We find that, as the average tariff goes down, the relative wage of informal to formal workers increases over time. This result is valid for the whole economy, i.e., the interaction term between the national average tariff and the indicator variable for the non-tradable sector is not statistically significant. This is consistent with a general equilibrium wage adjustment whereby workers move across sectors and industry wage premiums disappear.

The improvement of informal wages relative to formal wages offers a plausible explanation of the general equilibrium reduction in the informality rate in the manufacturing sector. When workers move across sectors, part of the unemployed labor force from the manufacturing industries is absorbed in the same sector at a lower wage. The reduction in the cost of formal employment results in a lower informality rate. In the non-tradable sector, the improvement of informal wages with respect to formal wages indicates that the increase in the informality rate seems due to the entry of new firms that start small and informal.

\section{Conclusions}

This paper examined the link between trade liberalization and labor informality in Argentina using a long time series spanning the 1980-2001 period. This was a period of sizeable tariff cuts and of increasing labor informality. Following Galiani and Porto (2010), we were able to disentangle cross-section impacts, that operate at the industry level, and time-series impacts, that operate at a general equilibrium level. Our findings indicated, first, that trade liberalization increased labor informality at the industry level, 
Table 7 Average tariff and wage differentials formal and informal workers OLS and IV estimators

\begin{tabular}{|c|c|c|c|c|c|c|}
\hline \multirow{2}{*}{$\begin{array}{l}\text { Dep. var.: } \\
\text { residual wage } \\
\text { differential }\end{array}$} & \multicolumn{3}{|l|}{ OLS } & \multicolumn{3}{|l|}{ IV } \\
\hline & (1) & $(2)$ & (3) & (4) & $(5)$ & (6) \\
\hline \multicolumn{7}{|c|}{ A) Definition 1: share of small-size firms in industry } \\
\hline $\begin{array}{l}\text { Log of average } \\
\text { tariff }\end{array}$ & $-0.116[0.058]^{*}$ & $-0.117[0.068]^{*}$ & $-0.003[0.112]$ & $-0.274[0.140]^{*}$ & $-0.358[0.178]^{*}$ & $-0.377[0.203]^{*}$ \\
\hline $\begin{array}{l}\text { Log of average } \\
\text { tariff* NT }\end{array}$ & $-0.121[0.105]$ & -0.108 [0.112] & $-0.130[0.124]$ & -0.258 [0.195] & $-0.202[0.216]$ & $-0.261[0.244]$ \\
\hline Observations & 64 & 64 & 64 & 64 & 64 & 64 \\
\hline$R^{2}$ & 0.45 & 0.46 & 0.505 & & & \\
\hline \multicolumn{7}{|l|}{ First stage result } \\
\hline \multicolumn{7}{|c|}{ Log of average tariff } \\
\hline Average $z^{2}$ & & & & $-0.633[0.190]^{* * *}$ & $-0.505[0.174]^{* * *}$ & $-0.474[0.137]^{* * *}$ \\
\hline $\begin{array}{l}\text { Average } z^{2} \\
\quad * N T\end{array}$ & & & & $0.006[0.214]$ & $-0.044[0.198]$ & $0.110[0.158]$ \\
\hline$R^{2}$ & & & & 0.34 & 0.49 & 0.69 \\
\hline \multicolumn{7}{|c|}{ Log of average tariff* NT } \\
\hline Average $z^{2}$ & & & & $-0.059[0.156]$ & $0.049[0.143]$ & $0.062[0.136]$ \\
\hline $\begin{array}{l}\text { Average } z^{2} \\
\quad * N T\end{array}$ & & & & $-0.533[0.176]^{* * *}$ & $-0.579[0.162]^{* * *}$ & $-0.510[0.156]^{* * *}$ \\
\hline$R^{2}$ & & & & 0.98 & 0.99 & 0.99 \\
\hline \multicolumn{7}{|c|}{ B) Definition 2: indicator of small-size industry } \\
\hline $\begin{array}{l}\text { Log of average } \\
\text { tariff }\end{array}$ & $-0.116[0.058]^{*}$ & $-0.117[0.068]^{*}$ & $-0.004[0.112]$ & $-0.275[0.139]^{*}$ & $-0.358[0.177]^{*}$ & $-0.378[0.202]^{*}$ \\
\hline $\begin{array}{l}\text { Log of average } \\
\text { tariff* NT }\end{array}$ & $-0.121[0.105]$ & $-0.107[0.111]$ & $-0.129[0.124]$ & $-0.256[0.195]$ & $-0.201[0.216]$ & -0.260 [0.243] \\
\hline Observations & 64 & 64 & 64 & 64 & 64 & 64 \\
\hline$R^{2}$ & 0.45 & 0.46 & 0.50 & & & \\
\hline \multicolumn{7}{|c|}{ First stage result } \\
\hline \multicolumn{7}{|c|}{ Log of average tariff } \\
\hline Average $z^{2}$ & & & & $-0.633[0.190]^{* * *}$ & $-0.505[0.174]^{* * *}$ & $-0.474[0.137]^{* * *}$ \\
\hline $\begin{array}{l}\text { Average } z^{2} \\
\quad * \mathrm{NT}\end{array}$ & & & & $0.006[0.214]$ & $-0.044[0.198]$ & $0.110[0.158]$ \\
\hline$R^{2}$ & & & & 0.34 & 0.49 & 0.688 \\
\hline \multicolumn{7}{|c|}{ Log of average tariff* NT } \\
\hline Average $z^{2}$ & & & & $-0.058[0.156]$ & $0.048[0.143]$ & $0.062[0.135]$ \\
\hline $\begin{array}{l}\text { Average } z^{2} \\
\quad * \mathrm{NT}\end{array}$ & & & & $-0.533[0.176]^{* * *}$ & $-0.579[0.162]^{* * *}$ & $-0.510[0.156]^{* * *}$ \\
\hline$R^{2}$ & & & & 0.98 & 0.99 & 0.99 \\
\hline $\begin{array}{l}\text { Log relative } \\
\text { supply }\end{array}$ & Yes & Yes & Yes & Yes & Yes & Yes \\
\hline $\begin{array}{l}\text { Log relative sup- } \\
\text { ply of informal } \\
\text { workers }\end{array}$ & No & Yes & Yes & No & Yes & Yes \\
\hline $\begin{array}{l}\text { Log relative sup- } \\
\text { ply of skilled } \\
\text { workers }\end{array}$ & No & Yes & Yes & No & Yes & Yes \\
\hline Linear time trend & No & No & Yes & No & No & Yes \\
\hline
\end{tabular}

Times series regressions of formal-informal residual wage differential on the national average tariff. Robust standard errors clustered by year and sector level in brackets. Average $z^{2}$ is the average of the instrument based on exchange rates of main partners weighted by the participation of each industry in total employment

*** Significant at $1 \%$

* Significant at 10\% 
and that the magnitude of this effect depended on the size of the firms in each industry. We argued that firms more exposed to tariff cuts substituted formal workers with informal workers for tax-evasion reasons and that this effect was differentially stronger in industries with a larger share of small-size firms. This result suggests that increasing tax evasion (in the form of hiring workers informally) worked as a strategy to smooth the negative trade shock. Second, evidence from time-series variation of the data established that, conditional on the structure of sectoral protection, labor informality in the manufacturing sector decreased as the average tariff fell, while the opposite occurred in the non-traded sector. These are general equilibrium effects caused by the reallocation of workers, the adjustment of relative formal and informal wages, and firm entry and exit.

Our findings using cross-sectional and time series data helped to explain some of the seemingly contradictory results in the previous literature. The empirical results also allowed us to rationalize some of the adjustments observed in countries following trade liberalization episodes. Moreover, we validated empirically the intuition that the tax evasion-formality channel is a relevant firm adjustment mechanism that allows some smoothing of the effect of the reforms. This additional adjustment mechanism operates in the sectors exposed to the trade reform, but also in the non-exposed sectors, and it constitutes a transmission mechanism for general equilibrium effects in developing countries beyond those documented for developed countries (e.g., Acemoglu et al. 2016). This may be one of the reasons why governments in developing countries seem reluctant to increase their enforcement efforts, at least during episodes of reform. While workers suffer in the form of lower quality jobs, this additional margin helps to maintain overall employment levels, and this is the trade-off faced by economic policy makers. However, by distinguishing between the within-industry adjustment and the general equilibrium effects, our results also indicated that there is an additional dimension for this trade-off. In Argentina's specific case, in general equilibrium labor informality fell in the tradable sector as a consequence of trade liberalization, but it increased in the non-tradable sector.

While greater labor mobility across sectors is usually seen as desirable, we provided an example of one more dimension where it would help economies and labor markets adjust to a new equilibrium with lower costs. In our case, it would allow for a smoother transition to the long-run equilibrium, avoiding the increase in labor informality and the emergence of unemployment. Moreover, a wider social protection net not linked to employment (as is the case with most of Latin America's social insurance systems) would mitigate the high costs for those workers that lose their social insurance benefits in the process of adjustment, and would reduce the incentive to evade taxes and hire workers informally.

Authors' contributions

All authors read and approved the final manuscript.

Author details

${ }^{1}$ Centro de Estudios Distrutivos, Laborales y Sociales (CEDLAS), Facultad de Ciencias Económicas (FCE), Departamento de Economía, Universidad Nacional de La Plata (UNLP), Argentina, Calle 6 e/ 47 y 48, Piso 3, Oficina 322, La Plata, Provincia de Buenos Aires, Argentina. ${ }^{2}$ Comisión Nacional de Investigaciones Científicas y Técnicas (CONICET), Buenos Aires, Argentina. ${ }^{3}$ Institute for the Study of Labor (IZA), Bonn, Germany. ${ }^{4}$ Departamento de Economía, Universidad Nacional de La Plata (UNLP), Argentina, Calle 6 e/ 47 y 48, Piso 3, Oficina 322, La Plata, Provincia de Buenos Aires, Argentina.

\section{Acknowledgements}

We thank I. Brambilla, F. Albornoz, N. Depetris Chauvin, J. C. Hallak, M. Olarreaga, and seminar participants at Universidad Nacional de La Plata, Universidad de San Andrés, and 2nd IZA@DC Young Scholar Program 2013. The referees and the Editor provided very detailed and useful comments that are greatly appreciated. Guido Porto acknowledges support from the R4D on Employment funded by Swiss National Science Foundation and the Swiss Development Cooperation. 


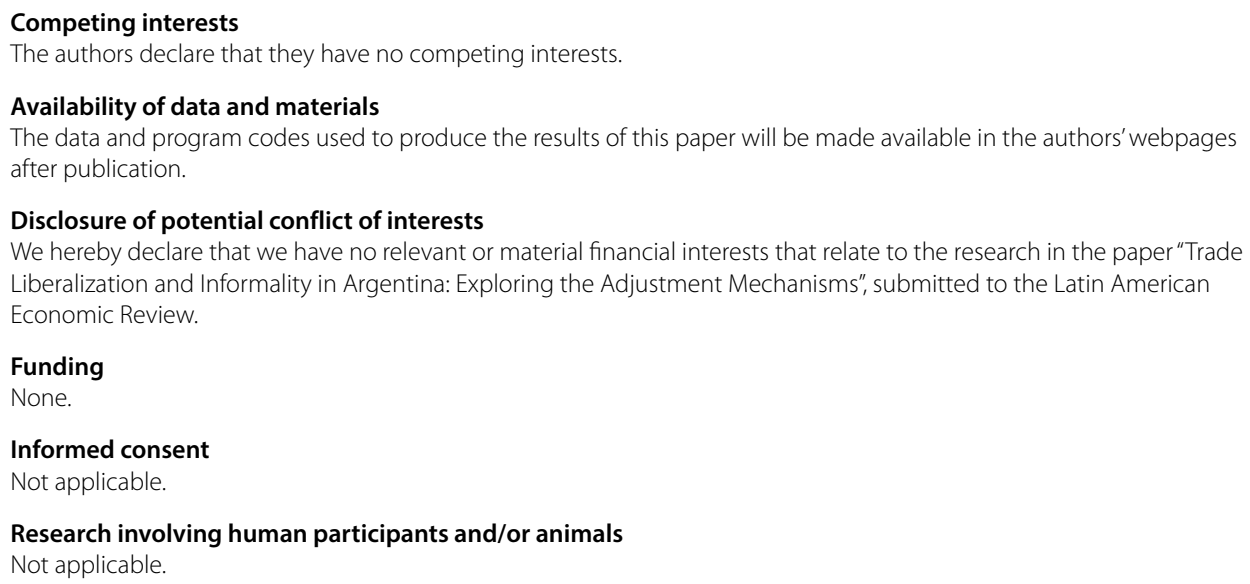

\section{Appendix}

\section{A. Robustness check: instrumenting for informality status}

We explore estimating model (6) by IV using $z_{j t}^{1}$ and $z_{j t}^{2}$ to instrument sectoral tariffs, and instrumenting the informality status $d_{i j t}$ as well. Informality can be endogenous if a low formal wage, for instance, creates a preference for informal employment or if unobserved factors such as labor perspectives or job attributes are present. We propose an instrumental variable that is a function of the informality condition of other household members (Paz 2014; Pratap and y Quintin 2006; Olson 2002):

$$
z_{\text {iht }}^{3}= \begin{cases}d_{\text {hhead }, h} \text { if } i \neq \text { household head } \\ d_{\text {other }, h} \text { if } i=\text { household head }\end{cases}
$$

If individual $i$ from household $h$ is not the household head, we assign as instrument the informality condition of the household head $\left(d_{\text {hhead,h }}\right)$, while for household heads we assign as instrument the average of the informality condition of other household members $\left(d_{o t h e r}, h\right)$. We consider unemployed and inactive individuals that do not receive a pension as informal household members. The validity of the instrument relies on the extension of some of the social security components to other household members, such as the health insurance. ${ }^{12}$ The exclusion restriction requires that the informality condition of other household members could impact on the productivity and wage received by individual $i$ only through the impact on the informality status. ${ }^{13}$

The first stage results for a wage regression where $d_{i j t}$ is the explanatory variable of interest appeared in Table 8. First column shows a positive association between $z_{i h t}^{3}$ and $d_{i j t}$, indicating that the preferences for formality or informality are shared within the household. The result is confirmed when we control for firm's size (second column). Second stage results for model (6) are in Table 9. Our general conclusions regarding the lack of wage adjustment in the cross-section remain robust.

\footnotetext{
12 Galiani and Weinschelbaum (2011) find that secondary workers are less likely to operate formally than primary workers because they already enjoy some portion of the nonpecuniary benefits generated by the first worker.

13 The first stage for $d_{i j t}$ using $z_{i h t}^{3}$ as instrument captures the impact of tariffs on informal employment.
} 
Table 8 Informal status on the informality condition of other household members. Source: Own elaboration based on EPH

\begin{tabular}{lll}
\hline & $\boldsymbol{N} \mathbf{1}$ if informal & $\boldsymbol{1}$ if informal \\
\hline$z_{i j t}^{3}$ & $0.124[0.010]^{* * *}$ & $0.093[0.009]^{* * *}$ \\
Firm size & No & Yes \\
Observations & 20661 & 20661 \\
$R^{2}$ & 0.19 & 0.28 \\
\hline
\end{tabular}

Robust standard errors in brackets

*** Significant at $1 \%$

Table 9 Industry tariffs and wage differential; formal and informal workers; IV estimation Source: Own elaboration based on EPH and Galiani and Porto (2010)

\begin{tabular}{|c|c|c|}
\hline Dep. var.: logarithm of workers' hourly wages & (1) & $(2)$ \\
\hline \multicolumn{3}{|l|}{ A) Definition 1: share of small-size firms in industry } \\
\hline$=1$ if informal & $1.245[1.733]$ & $0.038[1.402]$ \\
\hline Log of tariffs & $-0.062[0.201]$ & $-0.035[0.167]$ \\
\hline$=1$ if informal ${ }^{*}$ Log of tariffs & $-0.48[0.582]$ & $-0.07[0.465]$ \\
\hline$=1$ if informal* ${ }^{*}$ og of tariffs $* S$ & & $-0.005[0.151]$ \\
\hline Observations & 20661 & 20661 \\
\hline \multicolumn{3}{|l|}{ B) Definition 2: indicator of small-size industry } \\
\hline$=1$ if informal & $1.245[1.733]$ & $0.341[1.588]$ \\
\hline Log of tariffs & $-0.062[0.201]$ & $-0.024[0.167]$ \\
\hline$=1$ if informal*Log of tariffs & $-0.48[0.582]$ & $-0.185[0.514]$ \\
\hline$=1$ if informal ${ }^{*}$ Log of tariffs ${ }^{*} S$ & & $0.019[0.079]$ \\
\hline Observations & 20661 & 20661 \\
\hline
\end{tabular}

Robust standard errors clustered by industry-year in brackets. Industry size $S$ defined based on the share of small firms in each industry in 1980 (panel A) and as a dummy indicating small industries in 1980 (panel B)

\section{B. Robustness check: switching regression model}

Our result variable $y$ (logarithm of hourly wage) is:

$$
y=\left\{\begin{array}{lll}
y_{2}^{*} & \text { if } & y_{1}^{*}>0 \\
y_{3}^{*} & \text { if } & y_{1}^{*} \leq 0
\end{array}\right.
$$

The model is defined by the following three equations:

$$
\begin{aligned}
& y_{1}^{*}=x_{1}^{\prime} \beta_{1}+\varepsilon_{1} \\
& y_{2}^{*}=x_{2}^{\prime} \beta_{2}+\varepsilon_{2} \\
& y_{3}^{*}=x_{3}^{\prime} \beta_{3}+\varepsilon_{3}
\end{aligned}
$$

Error terms have a jointly normal distribution with zero mean and normalized variance $\sigma_{1}^{2}=1$. The estimation method is the two-step Heckman procedure:

$$
\begin{aligned}
& E\left[y \mid x, y_{1}^{*}>0\right]=x_{2}^{\prime} \beta_{2}+\sigma_{12} \lambda\left(x_{1}^{\prime} \beta_{1}\right) \\
& E\left[y \mid x, y_{1}^{*} \leq 0\right]=x_{3}^{\prime} \beta_{3}-\sigma_{13} \lambda\left(-x_{1}^{\prime} \beta_{1}\right)
\end{aligned}
$$


Table 10 Industry tariffs and wage differential between formal and informal workers; switching regression model. Source: Own elaboration based on EPH and Galiani and Porto (2010)

\begin{tabular}{|c|c|c|c|c|}
\hline & \multicolumn{2}{|l|}{ (1) } & \multicolumn{2}{|l|}{ (2) } \\
\hline & Formal & Informal & Formal & Informal \\
\hline \multicolumn{5}{|c|}{ A) Definition 1: share of small-size firms in industry } \\
\hline Log of tariffs & $-0.164[1.512]$ & $-0.297[0.981]$ & $0.001[0.283]$ & $-0.126[0.493]$ \\
\hline Log of tariffs*S & $0.288[2.262]$ & $0.461[-3.871]$ & $-0.029[0.104]$ & $-0.050[0.213]$ \\
\hline Observations & 15,489 & 5,172 & 15,489 & 5,172 \\
\hline$R^{2}$ & 0.68 & 0.58 & 0.68 & 0.58 \\
\hline \multicolumn{5}{|c|}{ B) Definition 2: indicator of small-size industry } \\
\hline Log of tariffs & $-0.152[0.126]$ & $-0.234[0.505]$ & $-0.100[0.162]$ & $-0.168[0.383]$ \\
\hline Log of tariffs*S & $-0.963[0.885]$ & $-0.349[0.678]$ & $-0.034[0.090]$ & $-0.065[0.134]$ \\
\hline Observations & 15,489 & 5,172 & 15,489 & 5,172 \\
\hline$R^{2}$ & 0.67 & 0.56 & 0.68 & 0.58 \\
\hline
\end{tabular}

500 bootstrapped standard errors in brackets. Industry size $S$ defined based on the share of small firms in each industry in 1980 (panel A) and as a dummy indicating small industries in 1980 (panel B)

where $\lambda(z)=\frac{\phi(z)}{\varphi(z)}$, and $\phi($.$) is the normal density function and \varphi($.$) is the normal$ distribution.

The probability of informal employment was estimated in the first stage controlling for sex, age and its squared, civil status, indicator variables for education level and household head status, indicator variables for industry affiliation and time periods, and industry tariffs. In the second stage, we estimate two wage models, for formal and informal workers, including the inverse Mills ratio as an additional control variable $(\lambda(z))$.

Panel 1 of Table 10 shows the results obtained when we instrument for the log of tariffs in the first and second stage and the identification relies on the non-linearity of the Mills ratio. In panel 2, the selection equation uses an additional regressor for identification $\left(z_{i h t}^{3}\right)$. In both panels, we find that industry tariffs have no effects on formal and informal wages.

\section{Robustness checks: industry size definitions}

Our previous estimates were based on a standard criteria regarding industry size categories. The size threshold we used was 15 employees. In this section, we test whether our results are robust to alternative size thresholds.

First, we moved the threshold defining small-size firms to 25 employees (option 1). Second, we moved it to 5 employees (option 2). We then constructed the same two industry size variable following the previous criteria: the share of workers in firms of small size in each industry in 1980 (definition 1), and an indicator variable of small-size industry taking the value 1 when the share of workers in small-size firms in that industry in 1980 was at least 0.5 (definition 2).

Tables 11 and 12 report cross-section and general equilibrium impacts, respectively. Columns 1 and 2 in Table 11 summarize cross-section OLS results and Columns 3 and 4 present IV results. Panel A shows the results obtained when defining industry size according to definition 1 . Columns 1 and 2 shows that tariffs have a direct impact 


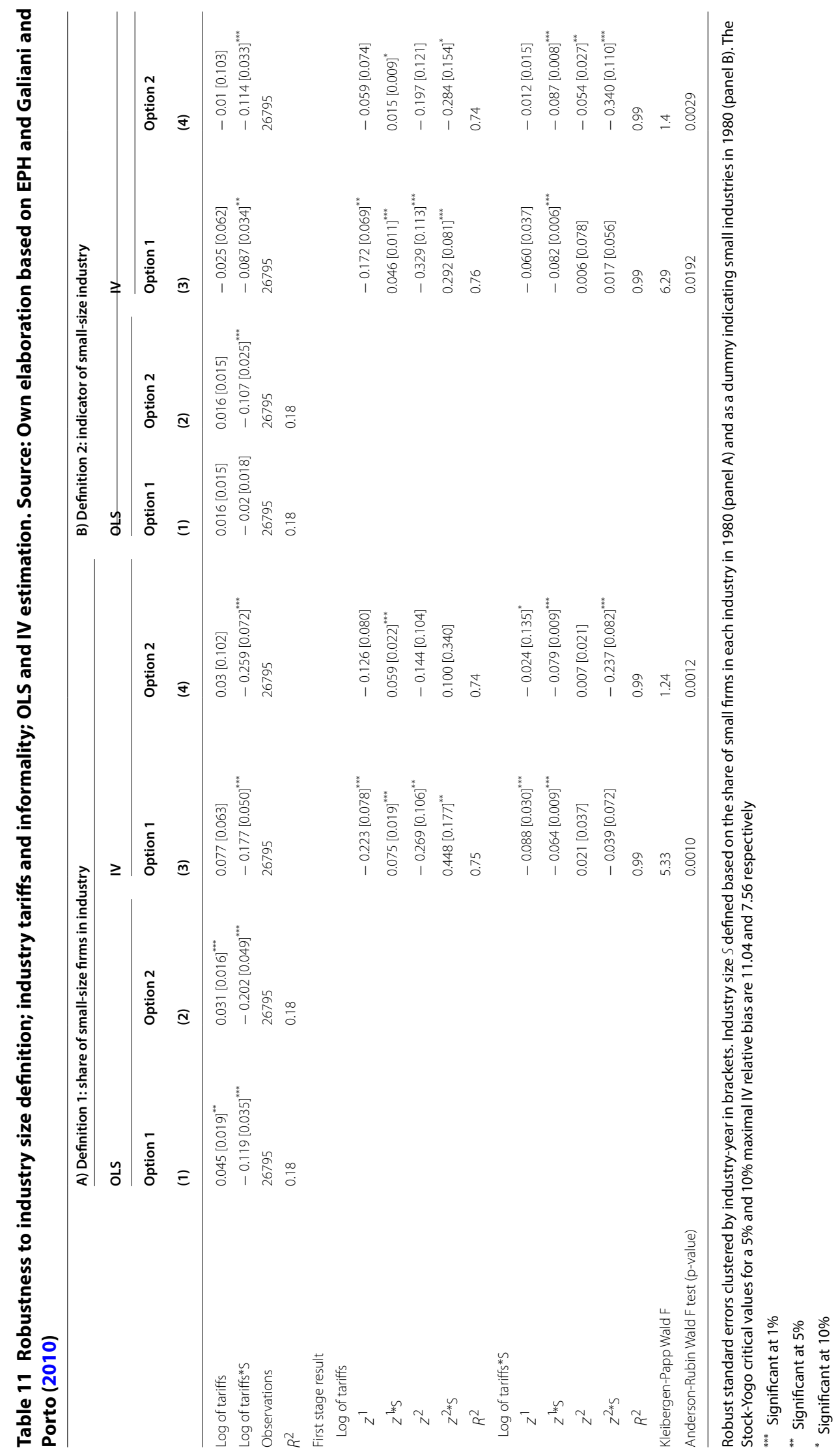




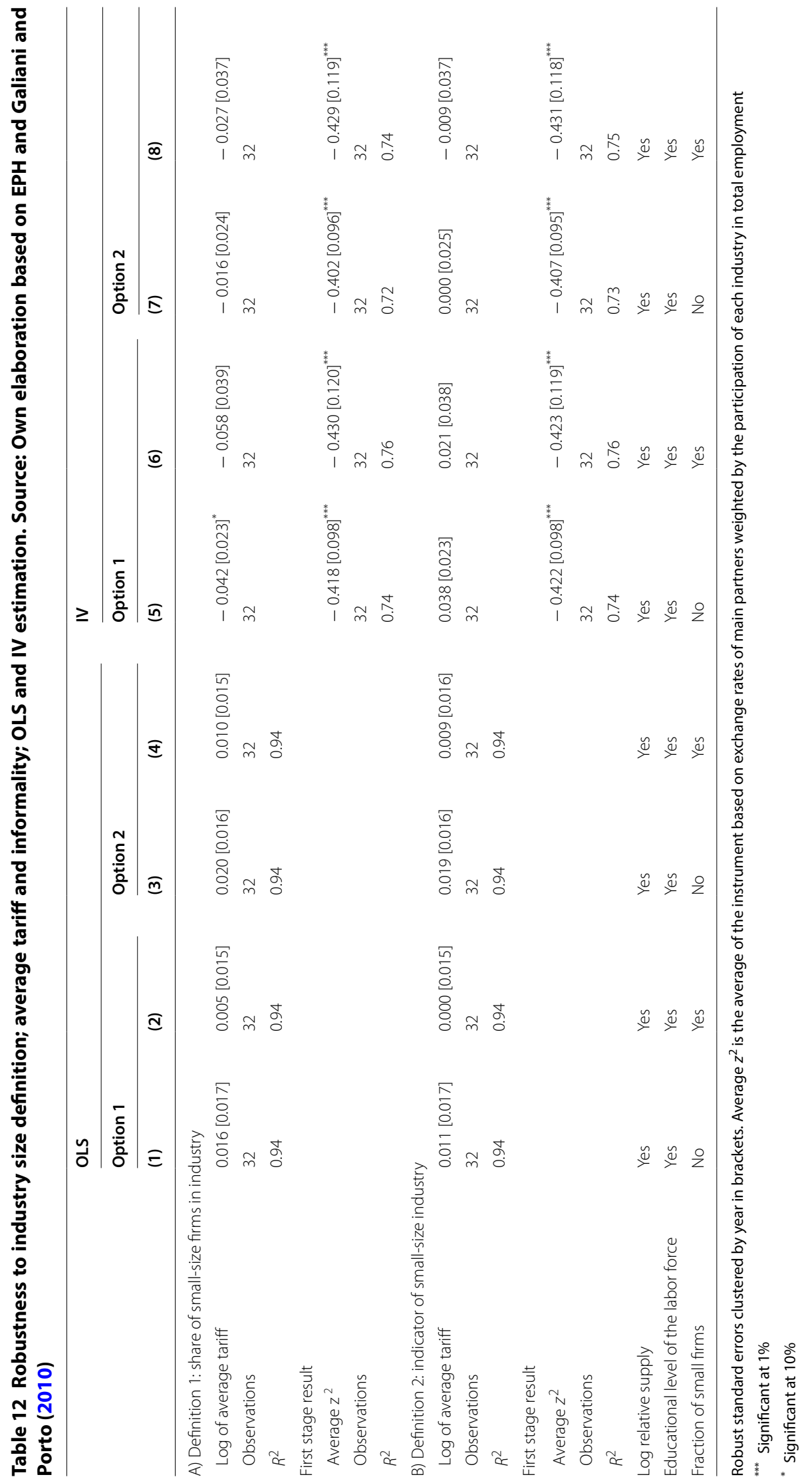


on the within-industry informality rate. The impact is positive in industries with a sufficiently small share of small-size firms, and becomes negative when the share of small-size firms increases. IV estimates in columns 3 and 4 show that reductions of industry tariffs lead to an increase in the within-industry informality and the impact increases with the share of small-size firms. Panel B presents the results when using definition 2 to construct the industry size variable. OLS estimates (columns 1 and 2 ) are robust to the new size threshold when using option 2 only (small-size firms defined as 5 employees or less). On the other hand, IV estimates are fully robust to the two alternative size thresholds employed. Time-series results reported in Table 12 show that we cannot identify any significant impact on the informality trend in the manufacturing sector at the usual significance levels regardless the definition of industry size, the estimation method and the size threshold option.

\section{Publisher's Note}

Publisher's NoteSpringer Nature remains neutral with regard to jurisdictional claims in published maps and institutional affiliations.

Received: 26 February 2018 Accepted: 1 November 2018

Published online: 04 December 2018

\section{References}

Acemoglu D, Autor D, Dorn D, Hanson G, Price B (2016) Import competition and the great US employment sag of the 2000s. J Labor Econ 34(S1):S141-S198

Acosta P, Montes-Rojas G (2014) Informal jobs and trade liberalisation in Argentina. J Dev Stud 50(8):1104-1118

Alemán-Castilla B (2006) The effect of trade liberalization on informality and wages: evidence from Mexico. CEP Discussion Paper 763

Arias J, Artuc E, Lederman D, Rojas D (2013) Tarde, informal employment and labor adjustment costs. Policy Research Working paper 6614. The World Bank

Artuc E, Chaudhuri S, McLaren J (2010) Trade shocks and labor adjustment: a structural empirical approach. Am Econ Rev 100(3):1008-1045

Atolia M (2007) Trade liberalization and rising wage inequality in Latin America: reconciliation with HOS theory. J Int Econ 71:467-494

Bérgolo M, Cruces G (2014) Work and tax evasion incentive effects of social insurance programs: evidence from an employment-based benefit extension. J Public Econ 117:211-228

Bernard A, Jensen J (1995) Exporters, jobs, and wages in U.S. Manufacturing: 1976-1987. Brooking papers on economic activity: microeconomics, pp 67-119

Bosch M, Goñi E, Maloney W (2012) Trade liberalization, labor reforms and formal-informal employment dynamics. Labour Econ 19(5):653-667

Brambilla I, Lederman D, Porto G (2012) Exports, export destinations and skills. Am Econ Rev 102(7):3406-3438

Bustos P (2011) Trade liberalization, exports, and technology upgrading: evidence on the impact of MERCOSUR on Argentinian firms. Am Econ Rev 101(1):304-40

Currie J, Harrison A (1997) Sharing the costs: the impact of trade reform on capital and labor in Morocco. J Labor Econ 15(3):44-71

Dix-Carneiro R (2014) Trade liberalization and labor market dynamics. Econometrica 82(3):825-885

Dix-Carneiro R, Kovak B (2015) Trade liberalization and labor market dynamics. NBER Working Paper 20908, National Bureau of Economic Research

Dix-Carneiro R, Kovak B (2017) Trade liberalization and regional dynamics. Am Econ Rev 107(10):2908-2946

Galiani S, Porto G (2010) Trends in Tariff reforms and trends in the structure of wages. Rev Econ Stat 92(3):482-494

Galiani S, Weinschelbaum F (2011) Modeling informality formally: households and firms. Econ Inq 50:821-838

Goldberg P, Pavcnik N (2003) The response of the informal sector to trade liberalization. J Dev Econ 72:463-496

Goldberg P, Pavcnik N (2007) Distributional effects of globalization in developing countries. J Econ Lit 45(1):39-82

Kleven H, Kreiner C, Saez E (2009) Why can modern governments tax so much? An agency model of firms as fiscal intermediaries. NBER Working Paper 15218

Levy S (2008) Good intentions, bad outcomes: Social policy, informality, and economic growth in Mexico. Brookings Institution Press, Washington, D.C

Menezes-Filho N, Muendler M (2011) Labor reallocation in response to trade reform. NBER Working Papers 17372, National Bureau of Economic Research

Montiel Olea JL, Pflueger C (2013) A robust test for weak instruments. J Bus Econ Stat 31 (3):358-369

Olson C (2002) Do workers accept lower wages in exchange for health benefits? J Labor Econ 20(2):S91-S114 
Park A, Yang D, Shi X, Jiang Y (2010) Exporting and firm performance: Chinese exporters and the Asian financial crisis. Rev Econ Stat 92(4):822-842

Paz $L$ (2014) The impacts of trade liberalization on informal labor markets: a theoretical and empirical evaluation of the Brazilian case. J Int Econ 92(2):330-348

Pratap S, y Quintin E (2006) Are labor markets segmented in developing countries? A semiparametric approach. Eur Econ Rev 50(7):1817-1841

Sánchez G, Butler I (2004) Market institutions, labor market dynamics, and productivity in Argentina during the 1990s. J Policy Reform 7(4):249-278

Topalova P (2010) Factor immobility and regional impacts of trade liberalization: evidence on poverty from India. Am Econ J Appl Econ 2(4):1-41

Wacziarg R, Wallack J (2004) Trade liberalization and intersectoral labor movements. J Int Econ 64(2):411-439

Submit your manuscript to a SpringerOpen ${ }^{\circ}$ journal and benefit from:

- Convenient online submission

- Rigorous peer review

- Open access: articles freely available online

- High visibility within the field

- Retaining the copyright to your article

Submit your next manuscript at $\boldsymbol{\nabla}$ springeropen.com 